\title{
Combined Analysis of S-Alleles in European Pear by Pollinations and PCR-based S-Genotyping; Correlation between S-Phenotypes and S-RNase Genotypes
}

\author{
Javier Sanzol ${ }^{1}$ \\ Unidad de Fruticultura, Centro de Investigación y Tecnología Agroalimentaria (CITA), Avenida de \\ Montañana 930, 50059 Zaragoza, Spain and Plant Science Division, School of Biosciences, \\ University of Nottingham, Sutton Bonington Campus, Loughborough LE12 5RD, United Kingdom
}

Timothy P. Robbins

Plant Science Division, School of Biosciences, University of Nottingham, Sutton Bonington Campus, Loughborough LE12 5RD, United Kingdom

\begin{abstract}
AdDITIONAL INDEX words. Pyrus communis, self-incompatibility, S-ribonuclease gene, consensus primers, allele-specific PCR

Abstract. Pollen-pistil incompatibility in european pear (Pyrus communis L.) compromises adequate orchard pollination and fruit set and restricts cross-fertility between cultivars suitable as parents in breeding programs. Genetic control is simple, with a single locus expressed gametophytically in pollen controlling the rejection of the pollen tube in the style. Semicompatible pollination arises when only one allele of a pollen parent matches the pistil. Semicompatible test-crosses using partially S-genotyped european pear cultivars allowed the discrimination of $14 \mathrm{~S}$ alleles $\left(S_{1}\right.$ to $\left.S_{14}\right)$ at the phenotypic level and the assignment of 33 cultivars to 13 incompatibility groups. Partial genomic sequences of the $\mathrm{S}-\mathrm{RNase}$ gene, spanning between the $\mathrm{C} 1$ and $\mathrm{C} 5$ conserved regions, were obtained for each new $S$-allele identified $\left(S_{6}\right.$ to $\left.S_{14}\right)$. These sequences and those reported previously for the $S_{1}$ to $S_{5}$ RNases allowed a set of consensus primers amplifying all $14 \mathrm{~S}-\mathrm{RN}$ ase alleles to be designed. Allele-specific PCR allowed discrimination between those S-RNases giving amplification products of similar size with consensus primers. These two approaches provided a method for the molecular identification of all $14 \mathrm{~S}$-alleles in european pear. With this methodology, we demonstrate that the S-RNase genotypes inferred from PCR exactly matches the S-phenotypes deduced from testcrosses. Comparison of the sequences obtained with those of $S$-RNases already published allowed us to relate $S$-alleles between studies. This will allow the prediction of cross-incompatibility among an even larger number of european pear cultivars.
\end{abstract}

European pear, like other fruit species of the Rosaceae, is impaired in effecting self-fertilization by a gametophytic self-incompatibility (GSI) system (Crane and Lewis, 1942). In the Rosaceae, GSI is inherited as a single multiallelic locus (S-locus) which controls both self-incompatibility and crossincompatibility among cultivars (de Nettancourt, 2001). Because the specificity of the incompatibility reaction relies on genes encoded by the S-locus, the cross-sterility or crossfertility of two diploid plants can be predicted in most cases

Received for publication 25 July 2007. Accepted for publication 16 Nov. 2007. J.S. was supported by the CAI-DGA Programme for European Mobility, an SIA postdoctoral fellowship, and a research contract from INIA-CCAA. Financial support for this work was provided by INIA (project grant RTA01-103) and CICYT (project grants AGL2003-05318-C02-01 and AGL2006-13529-C02-02). Sequences reported in this article have been submitted to the NCBI GenBank and are deposited under the following accession numbers: EF418037 $\left(\mathrm{S}_{6}-\right.$ RNase), EF418038 ( $\mathrm{S}_{7}-\mathrm{RNase}$ ), EF418039 ( $\mathrm{S}_{8}$-RNase), EF418040 ( $\mathrm{S}_{9}$-RNase), EF418041 ( $\mathrm{S}_{10}$-RNase), EF418042 ( $\mathrm{S}_{11}$-RNase), EF418043 ( $\mathrm{S}_{12}$-RNase), EF418044 ( $\mathrm{S}_{13}$-RNase), and EF418045 ( $\mathrm{S}_{14}$-RNase).

The authors thank María Herrero (EEAD, Spain) for support and discussion during the development of this work and critically reading the manuscript; Kenneth R. Tobutt (EMR, U.K.) for critically reading the manuscript; Reyes López (EEAD, Spain) for assistance during the pollination experiments; and Pilar Mozas and Santiago Uranga (Genomics and Sequencing Service, University of Zaragoza, Spain) for help and advice during DNA sequencing.

${ }^{1}$ Corresponding author. E-mail: jsanzol@aragon.es. solely on the basis of their S-genotypes. S-genotyping is therefore a priority of cultivar characterization in many fruit species because this provides growers and breeders with valuable information to avoid the selection of incompatible combinations of cultivars when designing plantations or performing crosses in breeding programs (Kester et al., 1994; Tehrani and Lay, 1991). Test-crosses to characterize cross-(in)compatibilities among cultivars, together with the knowledge of their pedigrees, have traditionally been the basis for the assignment of S-genotypes in a number of species (Crane and Brown, 1937; Kester et al., 1994; Kobel et al., 1939). More recently, the finding that the S-locus encodes a ribonuclease (S-RNase) in the Rosaceae (Bošković and Tobutt, 1996; Broothaerts et al., 1995) has allowed further development of biochemical and molecular strategies for S-genotyping.

The majority of the molecular methods for S-genotyping are based on polymorphisms of the S-RNase gene. Initial attempts to identify S-RNases associated with S-alleles were based on the existing knowledge about the S-genotype constitutions of cultivars deduced from the assessment of their S-phenotypes after test-crosses. Classical descriptions of S-phenotypes were well known for apple (Malus $\times$ domestica Borkh.) (Kobel et al., 1939), sweet cherry (Prunus avium L.) (Crane and Brown, 1937), japanese pear (Pyrus pyrifolia L.) [Terami et al., (1946), 
cited in Ishimizu et al. (1999)], and almond [Prunus dulcis (Mill.) Webb] (Kester et al., 1994). In european pear, similar studies have been lacking until recently, and reports on crossincompatibilities between cultivars have been merely anecdotal (Crane and Lewis, 1942; Le Lézec, 1998; Modlibowska, 1945) and insufficient for the systematic identification of S-alleles. Recently, by means of crossing experiments we identified four S-alleles $\left(\mathrm{S}_{1}-\mathrm{S}_{4}\right)$ in a group of cultivars on the basis of their pedigree and cross-(in)compatibility relationships (Sanzol and Herrero, 2002). With the identification of S-RNase genomic sequences associated with each S-allele, we were able to establish an initial correspondence between S-phenotypes as determined by crossing and S-RNase genotypes as detected by PCR and sequence analysis (Sanzol et al., 2006).

Since the first report characterizing S-RNases in european pear (Zuccherelli et al., 2002), sequences for 18 different alleles have been published (Moriya et al., 2007; Sanzol et al., 2006; Takasaki et al., 2006; Zisovich et al., 2004). With the exception of the $\mathrm{S}_{\mathrm{o}}$ allele, full-length cDNA and genomic sequences have now been obtained for all the S-RNases (Moriya et al., 2007; Takasaki et al., 2006). This information has been used for the S-genotyping of a large number of cultivars under the assumption that different S-RNase sequences are associated with different allelic specificities (Moriya et al., 2007; Takasaki et al., 2006; Zisovich et al., 2004; Zuccherelli et al., 2002). However, the extensive S-RNase-based genotyping developed in recent years contrasts with the limited information available on S-alleles characterized at the phenotypic level.

The aim of this work was to identify S-alleles in european pear by means of pollinations and subsequently analyze the correspondence between S-phenotypes and S-RNase genotypes. Following an approach based on the use of semicompatible cultivars, we were able to discriminate a total of $14 \mathrm{~S}$ haplotypes and assign 33 cultivars to 13 incompatibility groups. $\mathrm{S}-\mathrm{RNase}$ genomic sequences were identified for each S-allele. The correspondence between S-phenotypes and S-genotypes assigned to each cultivar was demonstrated by a combined use of consensus and allele-specific PCR.

\section{Materials and Methods}

Experimental Design. To identify new S-alleles and crossincompatibilities in european pear, we adopted the following strategy. First, we identified cultivars with S-genotypes sharing one S-allele (named as the common allele) while the second $\mathrm{S}$-allele for each cultivar was unknown. This group of cultivars was designated as the testing group. Next, we identified cultivars bearing the common allele, and one of the other S-alleles we have characterized so far $\left(\mathrm{S}_{1}-\mathrm{S}_{5}\right.$; Sanzol et al., 2006). Thus, if the $S_{1}$ allele was selected as the common allele, the four reference cultivars would have $\mathrm{S}$-genotypes with a combination of $\mathrm{S}_{1}$ and $\mathrm{S}_{2}-\mathrm{S}_{5}$ alleles, respectively. A particular characteristic of european pear breeding is the recurrent use of 'Williams' or its derivatives as a parent. As a consequence, a substantial number of cultivars developed over recent decades are direct descendents of this cultivar (Table 1). Thus, S-alleles present in 'Williams' $\left(S_{1} S_{2}\right)$ were selected as candidates to be used as the common allele. Crossing cultivars belonging to the group of the testing cultivars with those belonging to the group of the reference cultivars provided us with the following information. If a testing cultivar was cross-incompatible with a reference cultivar, this was identified as sharing the same
S-phenotype. Alternatively, whenever a testing cultivar was cross-compatible with all the cultivars included in the reference group, this indicated the presence of a new S-allele. Moreover, this cultivar was incorporated as a new reference genotype combining the common allele and the newly identified allele.

Plant material. A full list of the 63 cultivars used in this work is presented in Table 1. Flowers, pollen, and leaf material for DNA extraction were obtained from trees located at the Campus de Aula Dei experimental orchards (Zaragoza, Spain). Because of a lack of overlap in the flowering time or an insufficient number of flowers, we were unable to use some of the cultivars as female parents for some of the crosses. Also, pollen inviability of Magness compelled this cultivar to be used only as a female parent (Thompson et al., 1976). 'Beurré Alexander Lucas' and 'Merton Pride' were not included in the test-cross experiments on account of their triploidy.

POLLINATION PROCEDURES AND MICROSCOPIC PREPARATIONS. Test-crosses were performed as previously described (Sanzol and Herrero, 2002). Pollinations were performed during two different years, 2005 or 2006. Most of the crosses were performed during 2005, but some were repeated in 2006. Following fixation, pollinated pistils were prepared for the observation of pollen tubes growing into the ovules using the procedure described by Sanzol and Herrero (2002). A total of 50 ovules were scored for each cross under an Ortholux II microscope (Leitz Co., Wetzlar, Germany) with ultraviolet epifluorescence using a BP-355-425 exciter filter and an LP460 barrier filter. Data were expressed as the percentage of ovules or carpels with pollen tubes present.

Isolation OF GENOMic DNA AND PCR AMPlification. Total genomic DNA was prepared as described previously (Sanzol et al., 2006). DNA samples were diluted to a final concentration of $10 \mathrm{ng} \cdot \mu \mathrm{L}^{-1}$. PCR was performed using $50 \mathrm{ng}$ of genomic DNA in a $30-\mu \mathrm{L}$ reaction volume containing $1 \times$ reaction buffer (supplied with the enzyme), $2 \mathrm{~mm} \mathrm{MgCl}_{2}, 0.2 \mathrm{~mm}$ dNTPs, $0.6 \mu \mathrm{M}$ of each primer, and $0.8 \mathrm{U}$ of Taq DNA polymerase (Invitrogen, Carlsbad, CA). PCR amplification was conducted in an iCycler thermal cycler (Bio-Rad, Hercules, CA) with the following program: 2 min of denaturation at $94^{\circ} \mathrm{C} ; 36$ cycles of $30 \mathrm{~s}$ at $94^{\circ} \mathrm{C}, 1 \mathrm{~min}$ at specific annealing temperature, and $2 \mathrm{~min}$ at $72{ }^{\circ} \mathrm{C}$; and a final extension of $10 \mathrm{~min}$ at $72{ }^{\circ} \mathrm{C}$. Previously described degenerate primers (Fig. 1) MPyC1F (5'-ATT ATT WTC AAT TTA CGC AKC ART ATC AG-3') and MPyC5R (5' -CAA AKA SYR AYC TCR ACY AAT TCM G-3'), amplifying $\mathrm{S}-\mathrm{RNase}$ products associated with alleles $\mathrm{S}_{1}, \mathrm{~S}_{3}, \mathrm{~S}_{4}$, and $\mathrm{S}_{5}$ and specific amplification of the $\mathrm{S}_{1}$ and $\mathrm{S}_{2}$ using the reverse primer PycomS2R (5'-GTA ATG GTT CTT GTC TAT TAT TGT GG-3') were used as reported by Sanzol et al. (2006).

Cloning ANd SEQuence ANALysis. PCR products were cloned using the pGEM T-Easy cloning kit (Promega, Madison, WI). Cloned PCR products were sequenced in a MegaBACE 1000 capillary sequencer (Amersham Pharmacia Biotech, Uppsala, Sweden) at the Genomics and Sequencing Service of the University of Zaragoza (Zaragoza, Spain). PCR amplifications obtained using the MPyC1F/MPyC5R degenerate primers for the $\mathrm{S}_{6}, \mathrm{~S}_{7}, \mathrm{~S}_{8}, \mathrm{~S}_{9}, \mathrm{~S}_{11}$, and $\mathrm{S}_{14} \mathrm{~S}$-RNases were directly cloned and sequenced. However, degenerate primers did not amplify a PCR product putatively associated with alleles $\mathrm{S}_{10}, \mathrm{~S}_{12}$, and $\mathrm{S}_{13}$. Thus for these three alleles, the previous approach taken to identify the $\mathrm{S}_{2}$-associated S-RNase was adopted (Sanzol et al., 2006). Briefly, the forward primer MPyBC3F (5'-TGR HAR TTA TTT GGC CSA AYG-3') was used in combination with 
MPyC5R to obtain a 300-bp sequence different from the corresponding sequence for the $S_{1}$-RNase in 'Espadona' $\left(S_{1} S_{10}\right)$, 'Pierre Corneille' $\left(\mathrm{S}_{1} \mathrm{~S}_{12}\right)$, and 'Maxine' $\left(\mathrm{S}_{1} \mathrm{~S}_{13}\right)$. Based on these sequences, new reverse primers for each S-RNase were designed (5' -GAG ACC CAC AGA TGC CAT GTT TAG C-3' for $\mathrm{S}_{10} ; 5^{\prime}$-ATG TCG TCC CGT GTC CTG AAT CTA CC-3' for $\mathrm{S}_{12}$; and $5^{\prime}$-CTA TTG CGT ATG GCT ATT TCA AGA TC$3^{\prime}$ for $\mathrm{S}_{13}$ ) and used in combination with MPyC1F to complete an S-RNase sequence flanked by the $\mathrm{C} 1$ and $\mathrm{C} 5$ conserved regions for each S-allele, $S_{10}, S_{12}$, and $S_{13}$.

DESIGN OF CONSENSUS AND ALLELE-SPECIFIC PRIMERS. NeW consensus primers (Fig. 1) were thus designed amplifying all the S-RNase alleles reported in this work: forward orientation PycomC1F (5'-ATT TTC AAT TTA CGC AGC AAT ATC AGC-3') and reverse orientation PycomC5R (5'-CTG CAA AGW SHG ACC TCA ACC AAT TC-3'). The genomic sequences from the $\mathrm{C} 1$ to the $\mathrm{C} 5$ conserved regions of the 14 S-RNase alleles were aligned using ClustalX (Thompson et al., 1997). Variable regions were identified suitable for the design of reverse allele-specific primers which could be used together with the PycomC1F consensus primer and allowing the amplification of fragments not shorter than $300 \mathrm{bp}$. Allelespecific primers were thus designed for the $\mathrm{S}_{5}, \mathrm{~S}_{6}, \mathrm{~S}_{7}, \mathrm{~S}_{8}, \mathrm{~S}_{9}$, $\mathrm{S}_{11}, \mathrm{~S}_{12}$, and $\mathrm{S}_{14}$ RNases (Table 2). This was possible for all the alleles with the exception of $S_{7}$ and $S_{8}$ for which the design of an alternative forward primer was necessary to achieve allelespecific PCR. The primers developed for allele-specific PCR are summarized in Table 2 together with the annealing temperatures used and the sizes of the PCR products amplified. The standard PCR conditions and concentrations described above were also used for allele-specific PCR.

\section{Results and Discussion}

IDENTIFICATION OF TESTING CULTIVARS FOR THE COMMON ALLELE $\left(\mathbf{S}_{\mathbf{1}}\right)$. A group of 18 cultivars directly descended from cultivars genotyped as $\mathrm{S}_{1} \mathrm{~S}_{2}$, Williams (Sanzol and Herrero, 2002; Sanzol et al., 2006), Max Red Bartlett (a sport of Williams), or Seckel, which was earlier shown to be crossincompatible with Williams (Modlibowska, 1945) and later S-genotyped with the same S-RNase alleles (Takasaki et al., 2006), was initially selected to identify S-genotypes containing either the $S_{1}$ or $S_{2}$ alleles (Table 1; bold font). Genomic PCR amplifying $S_{1}$ and $S_{2}$ RNase indicated that 14 cultivars amplified the 1103-bp band associated with the $S_{1}$ allele, while three amplified the 1519-bp product associated with the $S_{2}$ allele and only Red Jewell amplified both (Table 1). Given the higher frequency of cultivars bearing $S_{1}$, this allele was selected for use as the common allele. The much greater proportion of these cultivars having the $S_{1}$ allele (15 out of 18 cultivars) compared with those having the $\mathrm{S}_{2}$ allele, was a priori an unexpected result because the transmission of the S-alleles from Williams (Bartlett) to its descendants has been shown to fit the ratio expected under nondistorted Mendelian segregation (Yamamoto et al., 2002). A plausible hypothesis to explain this observation is that the S-locus is linked to other gene(s) encoding a trait important for pear cultivation; thus the $\mathrm{S}_{1}$ allele has a selective advantage during breeding. Early work in sweet cherry showed that certain S-alleles were substantially more frequent, and selection for economic characters was suggested to explain this result (Williams and Brown, 1956). Recent genetic analyses in species belonging to distantly
Table 1. European pear cultivars analyzed in this study, parentages, and presence of $S_{1}(1103 \mathrm{bp})$ or $S_{2}(1519 \mathrm{bp})$ alleles after genomic PCR with primers MPyC1F and PycomS2R.

\begin{tabular}{|c|c|c|}
\hline Cultivar $^{z}$ & Parentage & $\begin{array}{c}\text { Product } \\
\text { size }(b p)^{y} \\
\end{array}$ \\
\hline Agua de Aranjuez & Unknown & 1103 \\
\hline Alexander Lucas & Unknown & 1103 \\
\hline Alexandrine Douillard & Unknown & - \\
\hline Aurore & $\begin{array}{l}\text { Marguerite } \\
\quad \text { Marillat } \times \text { Williams }\end{array}$ & 1103 \\
\hline Bella di Giugno & Unknown & - \\
\hline Beurré Bosc & Unknown & - \\
\hline Beurré d'Anjou & Unknown & 1103 \\
\hline Beurré Giffard & Unknown & 1103 \\
\hline Beurré Hardenport & Unknown & - \\
\hline Beurré Hardy & Unknown & - \\
\hline California & $\begin{array}{l}\text { Max Red Bartlett } \times \\
\text { Doyenne du Comice }\end{array}$ & 1103 \\
\hline Carmen & $\begin{array}{l}\text { Dr. Jules Guyot } \times \\
\text { Bella di Giugno }\end{array}$ & - \\
\hline Cascade & $\begin{array}{l}\text { Max Red Bartlett } \times \\
\text { Doyenne du Comice }\end{array}$ & 1103 \\
\hline Charles Ernest & Unknown & - \\
\hline Clapp's Favorite & Unknown & 1103 \\
\hline Concorde & $\begin{array}{l}\text { Conference } \times \\
\text { Doyenne du Comice }\end{array}$ & - \\
\hline Condo & Conference $\times ?$ & - \\
\hline Conference & Unknown & - \\
\hline Cura & Unknown & - \\
\hline Dawn & $\begin{array}{c}(\text { Barseck } \times \text { Williams }) \times \\
\text { Doyenne du Comice }\end{array}$ & - \\
\hline Delbard Premiere & Unknown & 1103 \\
\hline Dellette & Unknown & - \\
\hline Devoe & Unknown & - \\
\hline Director Hardy & Unknown & 1519 \\
\hline Dr. Jules Guyot & Unknown & 1103 \\
\hline EI Dorado & Williams $\times$ Winter Nelis & 1103 \\
\hline Epine du Mas & Unknown & - \\
\hline Espadona & Unknown & 1103 \\
\hline Etrusca & Coscia $\times$ Gentile & - \\
\hline Gentil Bianca & Unknown & 1103 \\
\hline Grand Champion & $\begin{array}{l}\text { Williams } \times \\
\text { Josephine de Malines }\end{array}$ & 1103 \\
\hline Harrow Delight & $\begin{array}{l}\text { Williams } \times \\
\quad(\text { Early Sweet } \times \text { Old Home })\end{array}$ & 1103 \\
\hline Harrow Sweet & Williams $\times$ Purdue $80-51$ & 1519 \\
\hline Highland & Williams $\times$ Doyenne du Comice & 1103 \\
\hline Jeanne d'Arque & $\begin{array}{l}\text { Beurré Diel } \times \\
\text { Doyenne du Comice }\end{array}$ & 1103 \\
\hline Louise Bonne & Unknown & $1103 / 1519$ \\
\hline Magness & Seckel $\times$ Doyenne du Comice & 1103 \\
\hline Maxine & Unknown & 1103 \\
\hline Merton Pride & Glou Morceau $\times$ Williams & 1103 \\
\hline Mondsallard & Unknown & - \\
\hline Norma & $\begin{array}{l}\text { Dr. Jules Guyot } \times \\
\text { Bella di Giugno }\end{array}$ & 1103 \\
\hline Onwards & $\begin{array}{l}\text { Laxton's Superb } \times \\
\text { Doyenne du Comice }\end{array}$ & 1103 \\
\hline Packhams Triumph & Bella Angevina $\times$ Williams & 1103 \\
\hline
\end{tabular}


Table 1. Continued.

\begin{tabular}{|c|c|c|}
\hline Cultivar $^{z}$ & Parentage & $\begin{array}{l}\text { Product } \\
\text { size }(b p)^{y}\end{array}$ \\
\hline Pierre Corneille & $\begin{array}{l}\text { Beurré Diel } \times \\
\text { Doyenne du Comice }\end{array}$ & 1103 \\
\hline Precoce di Fiorano & Beurré Giffard $\times$ Coscia & 1103 \\
\hline Precoce du Trévoux & Unknown & 1103 \\
\hline Precoce Morettini & Coscia $\times$ Williams & 1103 \\
\hline President Drouard & Unknown & - \\
\hline President Heron & Unknown & - \\
\hline Red Jewell & $\begin{array}{l}\text { Max Red Bartlett } \times \\
\text { Dr. Jules Guyot }\end{array}$ & $1103 / 151$ \\
\hline Rogue Red & $\begin{array}{l}\text { Doyenne du Comice } \times \\
\quad(\text { Seckel } \times \text { Farmingdale })\end{array}$ & - \\
\hline Santa $M^{\mathbf{a}}$ Morettini & Williams $\times$ Coscia & 1519 \\
\hline Sierre & Williams $\times$ Marguerite Marillat & 1103 \\
\hline Sirrine & Williams $\times ?$ & 1103 \\
\hline Spadona Estiva & Unknown & - \\
\hline Star & Unknown & 1103 \\
\hline Starkrimson & Flemish Beauty $\times$ Williams & 1103 \\
\hline Supercomice Delbard & Unknown & 1519 \\
\hline Tosca & Coscia $\times$ Williams & 1519 \\
\hline Turandot & $\begin{array}{l}\text { Dr. Jules Guyot } \times \text { Bella di } \\
\text { Giugno }\end{array}$ & - \\
\hline Wilder & Unknown & 1103 \\
\hline Williams & Unknown & $1103 / 15$ \\
\hline Winter Nellis & Unknown & - \\
\hline
\end{tabular}

${ }^{\mathrm{z} B o l d}$ font refers to cultivars descended from a cultivar of genotype $\mathrm{S}_{1} \mathrm{~S}_{2}$.

${ }^{y}$ Product sizes amplified using the primer pair $\mathrm{MPyC} 1 \mathrm{~F}$ and PycomS2R; “-_" = no amplification.

related taxa are in clear agreement with this possibility (Bernacchi and Tanksley, 1997; Burke et al., 2002; Gandhi et al., 2005).

An additional group of 44 cultivars most having unknown parents or at least one parent of unknown S-genotype were evaluated for $S_{1}$. Nineteen amplified the 1103-bp product associated with the $S_{1}$ allele (Table 1). Among them we could ascertain that the 1103-bp PCR products amplified from Beurré Giffard (a cultivar with unknown parents; Table 1) and Norma, unequivocally corresponded to the $\mathrm{S}_{1}$-associated $\mathrm{S}$-RNase.

Our crossing results showed that 'Precoce di Fiorano' is cross-incompatible with 'Agua de Aranjuez' $\left(\mathrm{S}_{1} \mathrm{~S}_{3}\right)$. Table 3

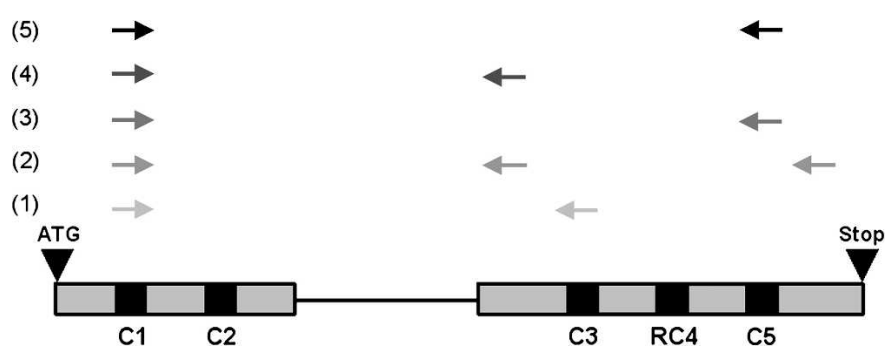

Fig. 1. Diagram of the S-RNase gene of european pear. Boxes represent the two exons containing five conserved regions $(\mathrm{C} 1-\mathrm{C} 3, \mathrm{RC} 4$, and $\mathrm{C} 5)$ and interrupted by the single intron of the gene (line). Arrows indicate the position of the consensus primers used by different authors and those reported in this study: (1) S1F/S1R (Zuccherelli et al., 2002), (2) FTQQYQ/anti-II(D/ $\mathrm{N}) \mathrm{CP}(\mathrm{H} / \mathrm{R})$ (Zisovich et al., 2004), (3) MPyC1F/MPyC5R (Sanzol et al., 2006), (4) FTQQYQ/anti(I/T)IWPNV (Takasaki et al., 2006), (5) PycomC1F/ PycomC5R (this study). shows the results of pollen tube performance for reciprocal crosses, self-pollinations, and cross-compatible crosses using 'Williams' as a control. We knew that 'Precoce di Fiorano' $\left(\mathrm{S}_{1} \mathrm{~S}_{3}\right)$, came from a cross between the cultivars Beurré Giffard and Coscia $\left(\mathrm{S}_{3} \mathrm{~S}_{4}\right.$; Sanzol and Herrero, 2002). Because 'Precoce di Fiorano' inherited the $\mathrm{S}_{3}$ allele from its male parent ('Coscia'), it should have received the $S_{1}$ allele from its seed parent ('Beurré Giffard'), confirming that the 1103-bp product from 'Beurre Giffard' corresponded to $\mathrm{S}_{1}$. On the other hand, 'Norma' is the result of a cross between 'Dr. Jules Guyot' and 'Bella di Giugno', only the first one genotyped with $\mathrm{S}_{1}$ (Table 1). Thus as the $\mathrm{S}_{1}$-associated amplification present in 'Norma' was inherited from its female parent ('Dr. Jules Guyot'), it was also genotyped with $\mathrm{S}_{1}$.

SElection of REFERENCE Genotypes $\left(\mathbf{S}_{1} \mathbf{S}_{2}\right.$ To $\left.\mathbf{S}_{\mathbf{1}} \mathbf{S}_{5}\right)$. Our previous work (Sanzol and Herrero, 2002) provided us with reference cultivars bearing the allelic combinations $\mathrm{S}_{1} \mathrm{~S}_{2}$ (Williams) and $\mathrm{S}_{1} \mathrm{~S}_{3}$ (Precoce Morettini and Agua de Aranjuez). To identify reference cultivars with the allelic combinations $\mathrm{S}_{1} \mathrm{~S}_{4}$ and $\mathrm{S}_{1} \mathrm{~S}_{5}$, we selected four cultivars containing the $\mathrm{S}_{1}$ allele (California, Cascade, Highland, and Magness), all of them descendants from a cross between an $\mathrm{S}_{1} \mathrm{~S}_{2}$-genotyped cultivar and Doyenne du Comice $\left(\mathrm{S}_{4} \mathrm{~S}_{5}\right)$ (Table 1). Intercrossing the four cultivars showed that Highland, California, and Cascade were cross-incompatible and cross-compatible with Magness (Table 4). This indicated that the first three cultivars bear the same S-allele inherited from Doyenne du Comice, while Magness received the other allele from this parent. SRNase genomic PCR using the primer combination (MPyC1F/ MPyC5R) amplified the 756-bp product associated with $\mathrm{S}_{4}$ from 'California', 'Cascade', and 'Highland' and the 651-bp associated with $\mathrm{S}_{5}$ only from 'Magness', in agreement with the crossing results. Two independent studies have reported 'Dr. Jules Guyot' to have S-alleles $\mathrm{S}_{\mathrm{e}}\left(=\mathrm{S}_{\mathrm{j}}\right.$ and $\left.\mathrm{S}_{1}\right)$ and $\mathrm{S}_{\mathrm{a}}$ (Takasaki et al., 2006; Zisovich et al., 2004). Sanzol et al. (2006) speculated that $S_{a}$ corresponded to $S_{5}$ characterized in 'Doyenne du Comice'. Table 4 shows that the cultivar Dr. Jules Guyot is cross-incompatible with Magness $\left(\mathrm{S}_{1} \mathrm{~S}_{5}\right)$, thus demonstrating that the alleles denominated as $\mathrm{S}_{\mathrm{a}}$ and $\mathrm{S}_{5}$ are indeed of the same specificity. In summary, reference cultivars for the S-genotypes $\mathrm{S}_{1} \mathrm{~S}_{4}$ and $\mathrm{S}_{1} \mathrm{~S}_{5}$ are Cascade, Highland, and California, and Magness and Dr. Jules Guyot, respectively.

Cross-(In)Compatibilities AND IDENTIFication OF NEW SALLELES. Cultivars representing the four reference genotypes $\left(\mathrm{S}_{1} \mathrm{~S}_{2}\right.$ to $\left.\mathrm{S}_{1} \mathrm{~S}_{5}\right)$ were crossed with the set of testing cultivars known to bear the $S_{1}$ allele (Table 3 ). A total of six crossincompatibilities were detected. Red Jewell was cross-incompatible with the reference cultivar Williams $\left(\mathrm{S}_{1} \mathrm{~S}_{2}\right)$, Packhams Triumph with the reference cultivars Agua de Aranjuez/ Precoce Morettini $\left(\mathrm{S}_{1} \mathrm{~S}_{3}\right)$, Grand Champion and Norma with the reference cultivar Highland $\left(\mathrm{S}_{1} \mathrm{~S}_{4}\right)$, and Aurore and Harrow Delight with the reference cultivar Dr. Jules Guyot $\left(\mathrm{S}_{1} \mathrm{~S}_{5}\right)$.

Beurré Giffard, El Dorado, Sierre, Sirrine, and Starkrimson were cross-compatible with all the reference cultivars, suggesting that they bear alleles different from $\mathrm{S}_{2}-\mathrm{S}_{5}$. A diallele cross with the five cultivars (Table 5) showed that Sierre and Starkrimson and that El Dorado and Sirrine were crossincompatible while all other combinations were cross-compatible, indicating that three new S-alleles were present in this group of cultivars. We therefore assigned $\mathrm{S}$-phenotypes $\mathrm{S}_{1} \mathrm{~S}_{6}$ to 'Beurré Giffard', $S_{1} S_{7}$ to 'El Dorado' and 'Sirrine', and $S_{1} S_{8}$ to 'Starkrimson' and 'Sierre'. 
Table 2. Primers and reaction conditions for allele-specific PCR of S-RNases in european pear.

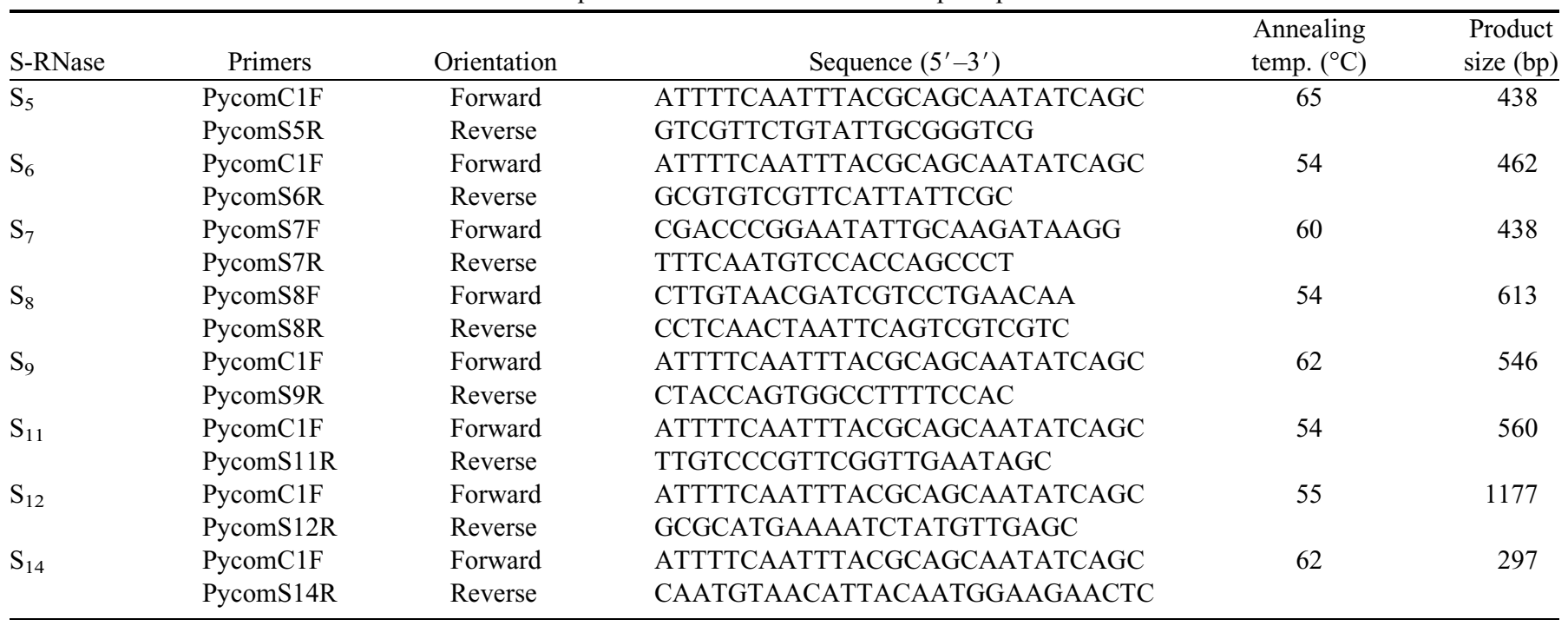

A similar analysis was extended to the remaining group of cultivars $\mathrm{S}$-genotyped with $\mathrm{S}_{1}$. Reference cultivars now representing genotypes $\mathrm{S}_{1} \mathrm{~S}_{2}$ to $\mathrm{S}_{1} \mathrm{~S}_{8}$, were crossed with the testing cultivars (Table 6) identifying seven cross-incompatibilities: Precoce du Trevoux and Louise Bonne with the reference cultivar Williams $\left(\mathrm{S}_{1} \mathrm{~S}_{2}\right)$ in agreement with an earlier report (Le Lézec, 1998; Osterwalder, 1910), Gentil Bianca with the reference cultivar Beurré Giffard $\left(\mathrm{S}_{1} \mathrm{~S}_{6}\right)$, Jeanne d'Arque and Onwards with the reference cultivar Highland $\left(\mathrm{S}_{1} \mathrm{~S}_{4}\right)$, and Star and Clapp's Favorite with the reference cultivar Starkrimson $\left(\mathrm{S}_{1} \mathrm{~S}_{8}\right)$. The cultivars Delbard Premiere, Wilder, Beurré d'Anjou, Espadona, Maxine, and Pierre Corneille were crosscompatible with all the reference genotypes, indicating the presence of alleles different from $\mathrm{S}_{1}-\mathrm{S}_{8}$. A diallele cross showed that the six cultivars were cross-compatible with each other, suggesting that the second allele for each cultivar was different (Table 7). We assigned S-phenotypes $\mathrm{S}_{1} \mathrm{~S}_{9}$ to 'Delbard Premiere', $\mathrm{S}_{1} \mathrm{~S}_{10}$ to 'Espadona', $\mathrm{S}_{1} \mathrm{~S}_{11}$ to 'Wilder', $\mathrm{S}_{1} \mathrm{~S}_{12}$ to 'Pierre Corneille', $\mathrm{S}_{1} \mathrm{~S}_{13}$ to 'Maxine', and $\mathrm{S}_{1} \mathrm{~S}_{14}$ to 'Beurré d'Anjou'.

The deduced S-phenotypes were in agreement with those expected after the parentage analysis of the cultivars, with the sole exceptions of Red Jewell and Pierre Corneille. The case of Red Jewell is of special interest because it is the result of the cross Max Red Bartlett $\left(\mathrm{S}_{1} \mathrm{~S}_{2}\right) \times$ Dr. Jules Guyot $\left(\mathrm{S}_{1} \mathrm{~S}_{5}\right)$, and so it was expected to have S-genotype $S_{1} S_{5}$ or $S_{2} S_{5}$. However, crossing results have shown 'Red Jewell' to have S-genotype $\mathrm{S}_{1} \mathrm{~S}_{2}$. If 'Red Jewell' received the $\mathrm{S}_{2}$ allele from its female parent, the $S_{1}$ allele should have been inherited from its male parent 'Dr. Jules Guyot', indicating that an incompatible pollen tube overcame the rejection reaction and effected fertilization. The chance for a pollen tube in such a case to avoid the selfincompatibility reaction is low if we consider that in a semicompatible cross, incompatible pollen tubes are competing with pollen tubes bearing a compatible S-allele. Such events have been observed for sweet cherry (a species for which the self-incompatibility reaction is considered to be more sharply defined than for pear) after the analysis of progeny coming from a semicompatible cross (Sonneveld et al., 2003). It follows that the chances for this phenomenon to be observed in pear are higher, particularly in a cross involving 'Williams' as a female, a cultivar considered to be partially self-incompatible (Griggs and Iwakiri, 1954). Indeed this is evident in terms of its pollen tube performance with levels of selfing substantially higher than any other cultivar analyzed so far by us (Table 3; Sanzol and Herrero, 2002).

IDENTIFICATION OF S-RNASE GENOMIC SEQUENCES ASSOCIATED WITH THE Alleles $\mathbf{S}_{\mathbf{6}}-\mathbf{S}_{\mathbf{1 4}}$. Putative genomic S-RNase sequences associated with the S-alleles $\mathrm{S}_{6}-\mathrm{S}_{14}$, were identified from 'Beurré Giffard' $\left(\mathrm{S}_{1} \mathrm{~S}_{6}\right)$, 'El Dorado' $\left(\mathrm{S}_{1} \mathrm{~S}_{7}\right)$, 'Starkrimson' $\left(\mathrm{S}_{1} \mathrm{~S}_{8}\right)$, 'Delbard Premiere' $\left(\mathrm{S}_{1} \mathrm{~S}_{9}\right)$, 'Espadona' $\left(\mathrm{S}_{1} \mathrm{~S}_{10}\right)$, 'Wilder' $\left(\mathrm{S}_{1} \mathrm{~S}_{11}\right)$, 'Maxine' $\left(\mathrm{S}_{1} \mathrm{~S}_{12}\right)$, 'Pierre Corneille' $\left(\mathrm{S}_{1} \mathrm{~S}_{13}\right)$, and 'Beurré d'Anjou' $\left(\mathrm{S}_{1} \mathrm{~S}_{14}\right)$. Cultivars representing reference genotypes with known S-RNases [Williams $\left(\mathrm{S}_{1} \mathrm{~S}_{2}\right)$, Precoce Morettini $\left(\mathrm{S}_{1} \mathrm{~S}_{3}\right)$, Highland $\left(\mathrm{S}_{1} \mathrm{~S}_{4}\right)$, and Magness $\left.\left(\mathrm{S}_{1} \mathrm{~S}_{5}\right)\right]$ gave the expected PCR products corresponding to each allele (Fig. 2A) using the $\mathrm{C} 1 / \mathrm{C} 5$ (MPyC1F/MPyC5R) pair of degenerate primers with the exception of the $\mathrm{S}_{2}$-RNase from Williams, which is not amplified by this primer pair (Sanzol et al., 2006). Cultivars with S-phenotypes $\mathrm{S}_{1} \mathrm{~S}_{6}$ to $\mathrm{S}_{1} \mathrm{~S}_{14}$ all amplified the 1306-bp band corresponding to $\mathrm{S}_{1}$ (Fig. 2A). In addition, 'El Dorado' $\left(\mathrm{S}_{1} \mathrm{~S}_{7}\right)$, 'Delbard Premiere' $\left(\mathrm{S}_{1} \mathrm{~S}_{9}\right)$, and 'Beurré d'Anjou' $\left(\mathrm{S}_{1} \mathrm{~S}_{14}\right)$, amplified a second PCR product of $\approx 650$ $\mathrm{bp}$, similar in size to the PCR product for $\mathrm{S}_{5}$. 'Beurré Giffard' $\left(\mathrm{S}_{1} \mathrm{~S}_{6}\right)$, 'Starkrimson' $\left(\mathrm{S}_{1} \mathrm{~S}_{8}\right)$, and 'Wilder' $\left(\mathrm{S}_{1} \mathrm{~S}_{11}\right)$ also amplified a second novel band of $\approx 675 \mathrm{bp}$. 'Espadona' $\left(\mathrm{S}_{1} \mathrm{~S}_{10}\right)$, 'Pierre Corneille' $\left(\mathrm{S}_{1} \mathrm{~S}_{12}\right)$, and 'Maxine' $\left(\mathrm{S}_{1} \mathrm{~S}_{13}\right)$ amplified only the PCR amplification for $\mathrm{S}_{1}$ (Fig. 2A).

These PCR products putatively associated with alleles $\mathrm{S}_{6}$, $\mathrm{S}_{7}, \mathrm{~S}_{8}, \mathrm{~S}_{9}, \mathrm{~S}_{11}$, and $\mathrm{S}_{14}$ were cloned and sequenced. The novel allelic S-RNase sequence from 'Espadona', 'Maxine', and 'Pierre Corneille' was obtained following the approach used previously to characterize the S-RNase associated with the $\mathrm{S}_{2}$ allele (Sanzol et al., 2006). Sequence analysis between the C1 and the $\mathrm{C} 5$ conserved regions confirmed that all the sequences obtained had the conserved and variable regions characteristics of the Maloideae S-RNase. As expected, all were different, consistent with cross-compatibility of all the cultivars.

To be consistent with the denomination of the S-alleles discriminated in this study at the phenotypic level and with the 


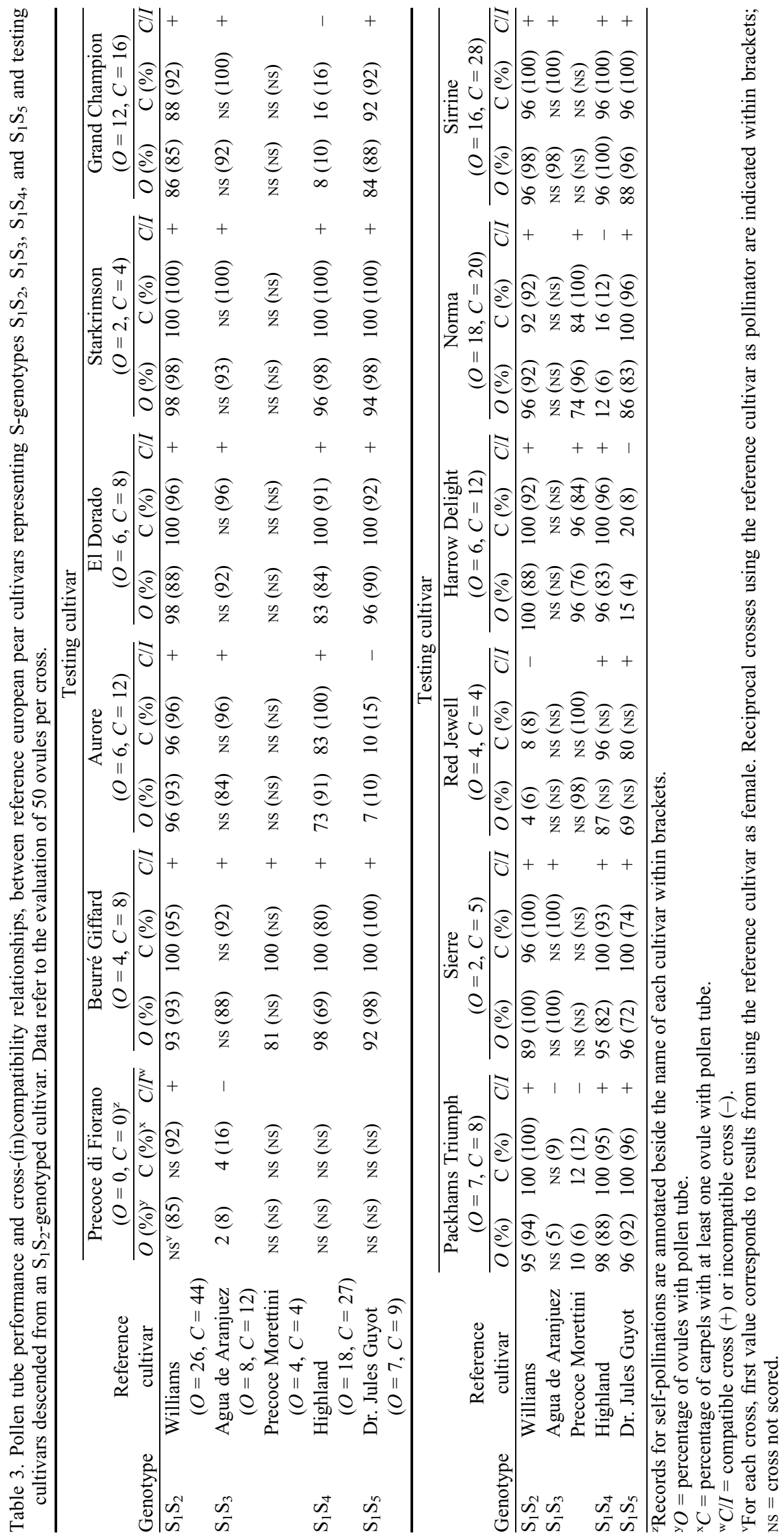


Table 4. Pollen tube performance and cross-(in)compatibility relationships between european pear cultivars, for the identification of $\mathrm{S}_{1} \mathrm{~S}_{4}$ and $\mathrm{S}_{1} \mathrm{~S}_{5}$ reference genotypes (data refer to the evaluation of 50 ovules per cross).

\begin{tabular}{|c|c|c|c|c|c|c|c|c|c|c|c|c|}
\hline \multirow[b]{3}{*}{ Pollinated cultivar } & \multicolumn{12}{|c|}{ Pollinator cultivar } \\
\hline & \multicolumn{3}{|c|}{ Highland } & \multicolumn{3}{|c|}{ Cascade } & \multicolumn{3}{|c|}{ California } & \multicolumn{3}{|c|}{ Dr. Jules Guyot } \\
\hline & $O(\%)^{\mathrm{z}}$ & $\mathrm{C}(\%)^{\mathrm{y}}$ & $C / I^{\mathrm{x}}$ & $O(\%)$ & $\mathrm{C}(\%)$ & $C / I$ & $O(\%)$ & $\mathrm{C}(\%)$ & $C / I$ & $O(\%)$ & $\mathrm{C}(\%)$ & $C / I$ \\
\hline Magness & 78 & 95 & + & 83 & 92 & + & & $\mathrm{NS}^{\mathrm{w}}$ & & 3 & 6 & - \\
\hline Cascade & 14 & 16 & - & 20 & 28 & - & 15 & 20 & - & 90 & 93 & + \\
\hline California & 14 & 20 & - & 19 & 29 & - & 18 & 24 & - & 83 & 91 & + \\
\hline Dr. Jules Gujot & 94 & 100 & + & 88 & 96 & + & 94 & 96 & + & 7 & 9 & - \\
\hline
\end{tabular}

${ }^{\mathrm{z}} \mathrm{O}=$ percentage of ovules with pollen tube.

${ }^{\mathrm{y}} \mathrm{C}=$ percentage of carpels with at least one ovule with pollen tube.

${ }^{\mathrm{x}} \mathrm{C} / \mathrm{I}=$ compatible cross $(+)$ or incompatible cross $(-)$.

${ }^{\mathrm{w}} \mathrm{NS}=$ cross not scored.

original work identifying S-alleles in european pear by Sanzol and Herrero (2002), the nine S-RNases we characterized were annotated following the same numerical series. On the basis of the sequences characterized, we correlated the nomenclature with the other annotation system used to denominate S-RNase alleles which is based on letters (Moriya et al., 2007; Takasaki et al., 2006; Zisovich et al., 2004; Zuccherelli et al., 2002) as shown in Table 8 . In a previous paper we proposed a unified nomenclature based on numbers to denominate S-alleles in european pear (Sanzol et al., 2006). Numbers are used for the annotation of S-alleles in the majority of the fruit tree species, including apple, japanese pear, almond, and sweet cherry. A numbering system is not limited by the number of labels available $(\mathrm{a}-\mathrm{z})$, and in the case of european pear it would resolve the problem of double-annotations already existing with the letter-based nomenclature [discussed by Sanzol et al. (2006)].

CORRESPONDENCE BETWEEN S-PHENOTYPES AND S-GENOTYPES. We attempted to confirm an association between the S-alleles we identified through pollinations and the S-RNase sequences we obtained. Genomic PCR using the primer combination (PycomC1F/PycomC5R) amplified characteristic PCR product sizes for $\mathrm{S}_{1}(\approx 1300 \mathrm{bp}), \mathrm{S}_{2}(\approx 1700 \mathrm{bp}), \mathrm{S}_{4}(\approx 750 \mathrm{bp}), \mathrm{S}_{10}$ $(\approx 2200 \mathrm{bp})$, and $\mathrm{S}_{13}(\approx 2000 \mathrm{bp})$; thus they could be accurately evaluated in terms of their amplification sizes. However, the S-RNase groups $\mathrm{S}_{3} / \mathrm{S}_{12}, \mathrm{~S}_{5} / \mathrm{S}_{7} / \mathrm{S}_{9} / \mathrm{S}_{14}$, and $\mathrm{S}_{6} / \mathrm{S}_{8} / \mathrm{S}_{11}$ amplified products of similar size using consensus primers, and they could not be easily distinguished after visualization of their PCR products on agarose gels (Fig. 2). For convenience, these product sizes were annotated under the general denominations of $1300 \mathrm{bp}$ for $\mathrm{S}_{3} / \mathrm{S}_{12}, 675 \mathrm{bp}$ for $\mathrm{S}_{6} / \mathrm{S}_{8} / \mathrm{S}_{11}$, and $650 \mathrm{bp}$ for $\mathrm{S}_{5} /$ $\mathrm{S}_{7} / \mathrm{S}_{9} / \mathrm{S}_{14}$, although actual sizes amplified for each S-RNase allele within each group were slightly different. We designed allele-specific primers to distinguish between the S-RNase alleles within these groups (Table 2). Allele-specific PCR for $\mathrm{S}_{5}, \mathrm{~S}_{6}, \mathrm{~S}_{9}, \mathrm{~S}_{11}, \mathrm{~S}_{12}$, and $\mathrm{S}_{14}$ used a reverse specific primer in combination with the PycomC1F consensus primer. However, allele-specific PCR for $\mathrm{S}_{7}$ and $\mathrm{S}_{8}$ used both forward and reverse specific primers. The specific primer pairs under the optimal annealing temperatures gave amplification products of the expected size from the cultivar used as reference for each Sallele (data not shown). No amplification products were obtained when cultivars containing the other S-alleles were tested.

By combining consensus and allele-specific PCR, we obtained the $S$-RNase genotypes for the 33 cultivars that were assigned to 13 incompatibility groups by pollination tests. Table 9 shows the amplification products obtained for each cultivar using consensus primers. As expected, all cultivars amplified two bands, one of which was common to all cultivars corresponding to $S_{1}$. The product size $(1700 \mathrm{bp})$ corresponding to $S_{2}$ was present exclusively in 'Williams', 'Precoce du Trevoux', 'Red Jewell', and 'Louise Bonne', all identified as $\mathrm{S}_{1} \mathrm{~S}_{2}$. Similarly, Highland, Cascade, Jeanne d'Arc, Onwards, California, Grand Champion, and Norma assigned to $S_{1} S_{4}$ were the only cultivars to amplify a product of $750 \mathrm{bp}$, corresponding to $\mathrm{S}_{4}$. Espadona and Maxine were single members of the incompatibility groups $\mathrm{S}_{1} \mathrm{~S}_{10}$ and $\mathrm{S}_{1} \mathrm{~S}_{13}$, respectively, and they were the only cultivars amplifying bands of 2200 and $1950 \mathrm{bp}$, respectively corresponding to $\mathrm{S}_{10}$ and $\mathrm{S}_{13}$. Using consensus

Table 5. Diallele cross involving the european pear cultivars descended from a cultivar genotyped as $\mathrm{S}_{1} \mathrm{~S}_{2}$ that were shown to be cross-compatible with all the reference cultivars representing genotypes $S_{1} S_{2}, S_{1} S_{3}, S_{1} S_{4}$, and $S_{1} S_{5}$ (data refer to the evaluation of 50 ovules per cross).

\begin{tabular}{|c|c|c|c|c|c|c|c|c|c|c|c|c|c|c|c|}
\hline \multirow[b]{3}{*}{ Pollinated cultivar } & \multicolumn{15}{|c|}{ Pollinator cultivar } \\
\hline & \multicolumn{3}{|c|}{ Beurré Giffard } & \multicolumn{3}{|c|}{ El Dorado } & \multicolumn{3}{|c|}{ Starkrimson } & \multicolumn{3}{|c|}{ Sierre } & \multicolumn{3}{|c|}{ Sirrine } \\
\hline & $O(\%)^{\mathrm{z}}$ & $\mathrm{C}(\%)^{\mathrm{y}}$ & $C / I^{\mathrm{x}}$ & $O(\%)$ & C (\%) & $C / I$ & $O(\%)$ & C (\%) & $C / I$ & $O(\%)$ & C (\%) & $C / I$ & $O(\%)$ & C (\%) & $C / I$ \\
\hline Beurré Giffard & & Table 3 & & 90 & 92 & + & 98 & 100 & + & 85 & 80 & + & 96 & 100 & + \\
\hline Starkrimson & 97 & 100 & + & 89 & 91 & + & & Table 3 & & 2 & 4 & - & & $\mathrm{NS}^{\mathrm{w}}$ & \\
\hline Sierre & 85 & 90 & + & 94 & 94 & + & 3 & 7 & - & & Table 3 & & 85 & 92 & + \\
\hline Sirrine & 96 & 96 & + & 10 & 13 & - & 100 & 100 & + & 92 & 96 & + & & Table 3 & \\
\hline
\end{tabular}

${ }^{\mathrm{z}} \mathrm{O}=$ percentage of ovules with pollen tube.

${ }^{\mathrm{y}} \mathrm{C}=$ percentage of carpels with at least one ovule with pollen tube.

${ }^{\mathrm{x}} \mathrm{C} / \mathrm{I}=$ compatible cross $(+)$ or incompatible cross $(-)$.

${ }^{{ }^{\mathrm{NS}}}=$ cross not scored. 


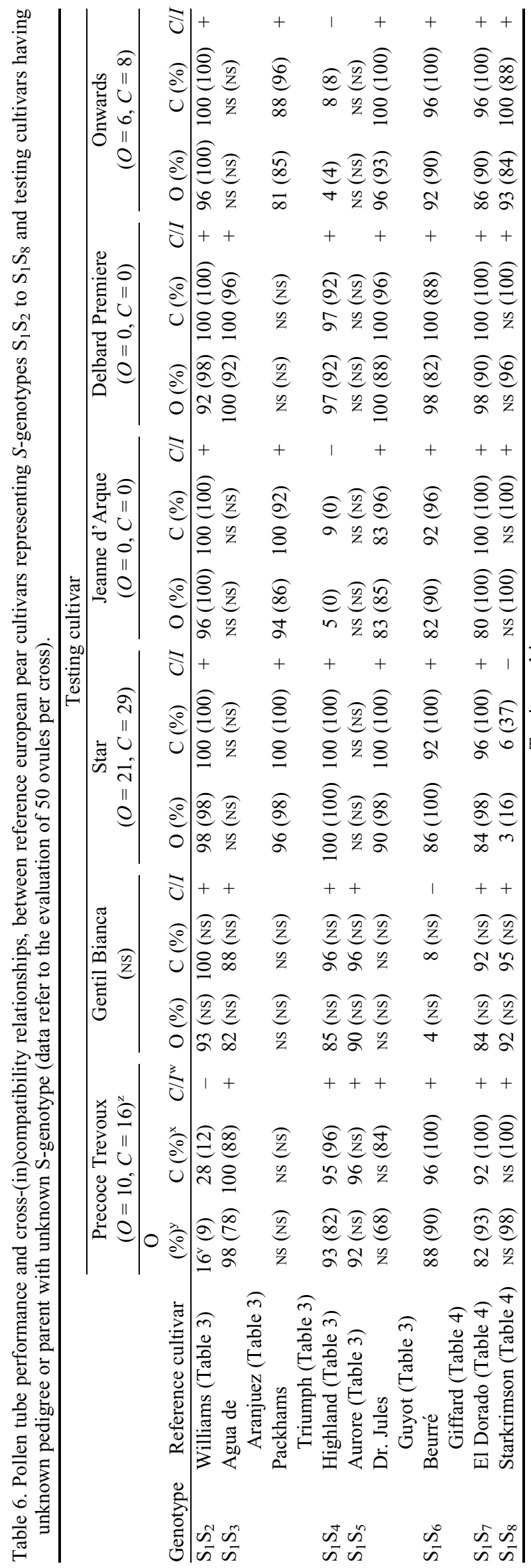

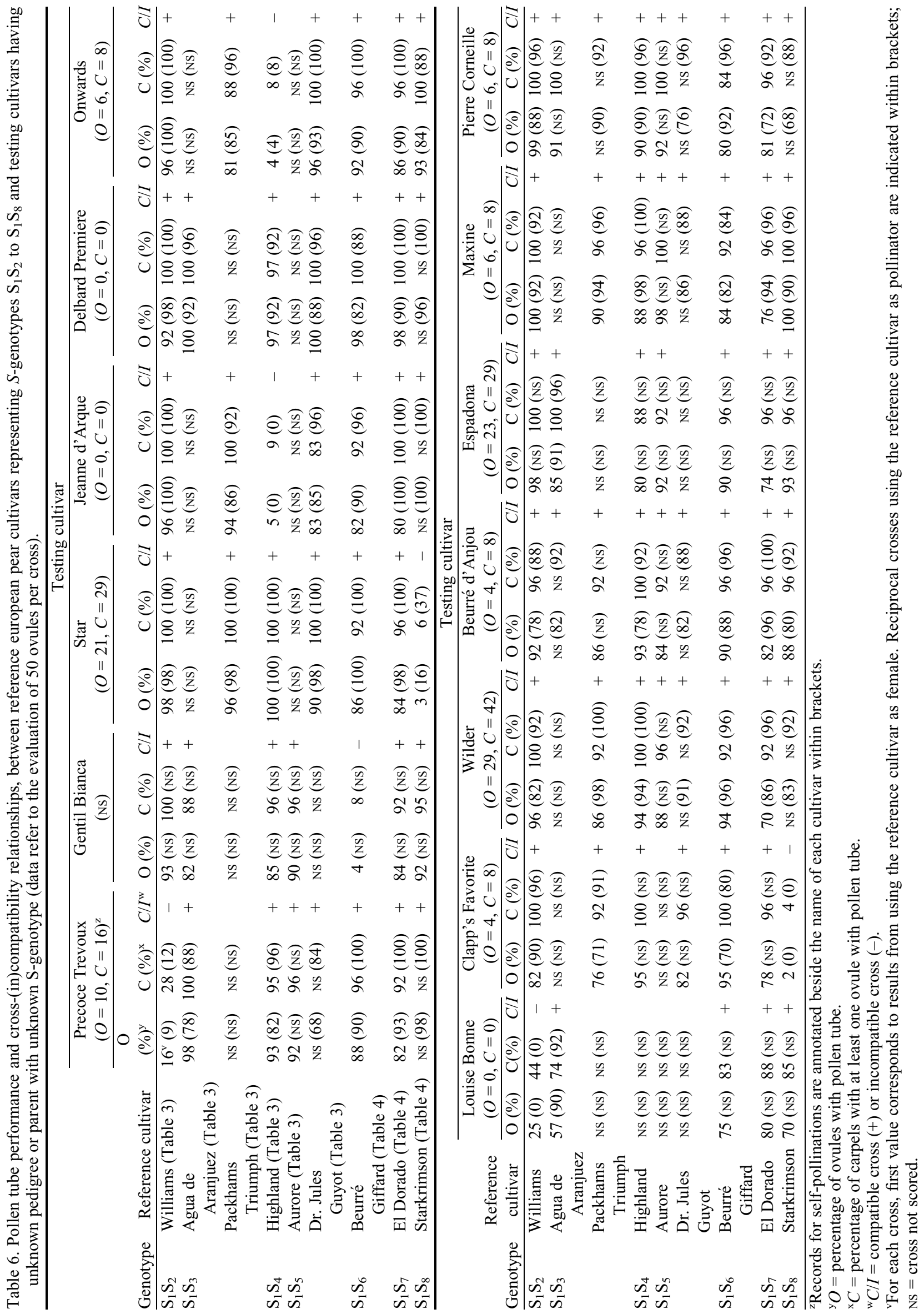

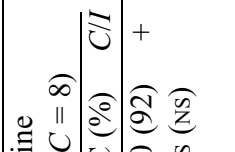

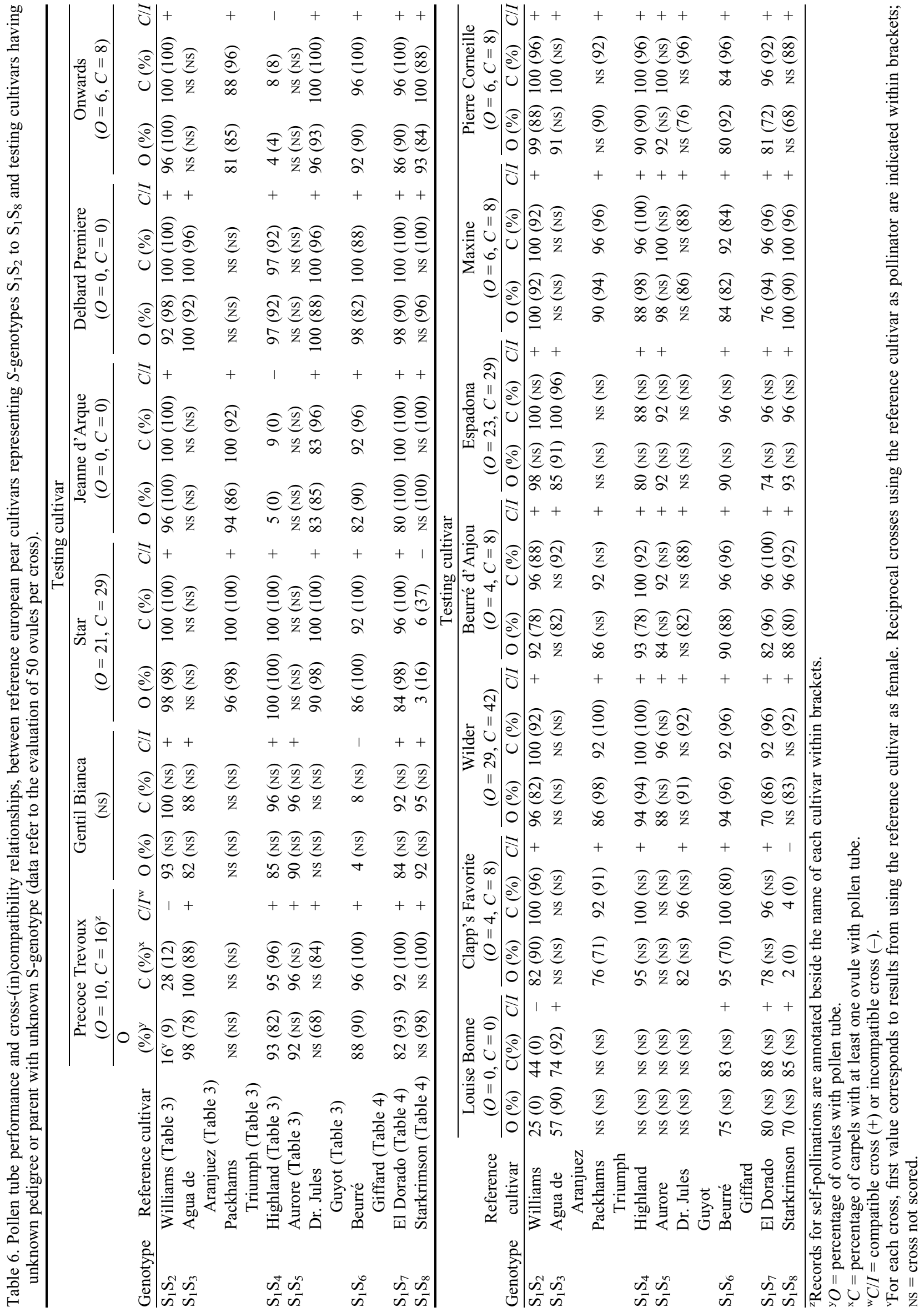

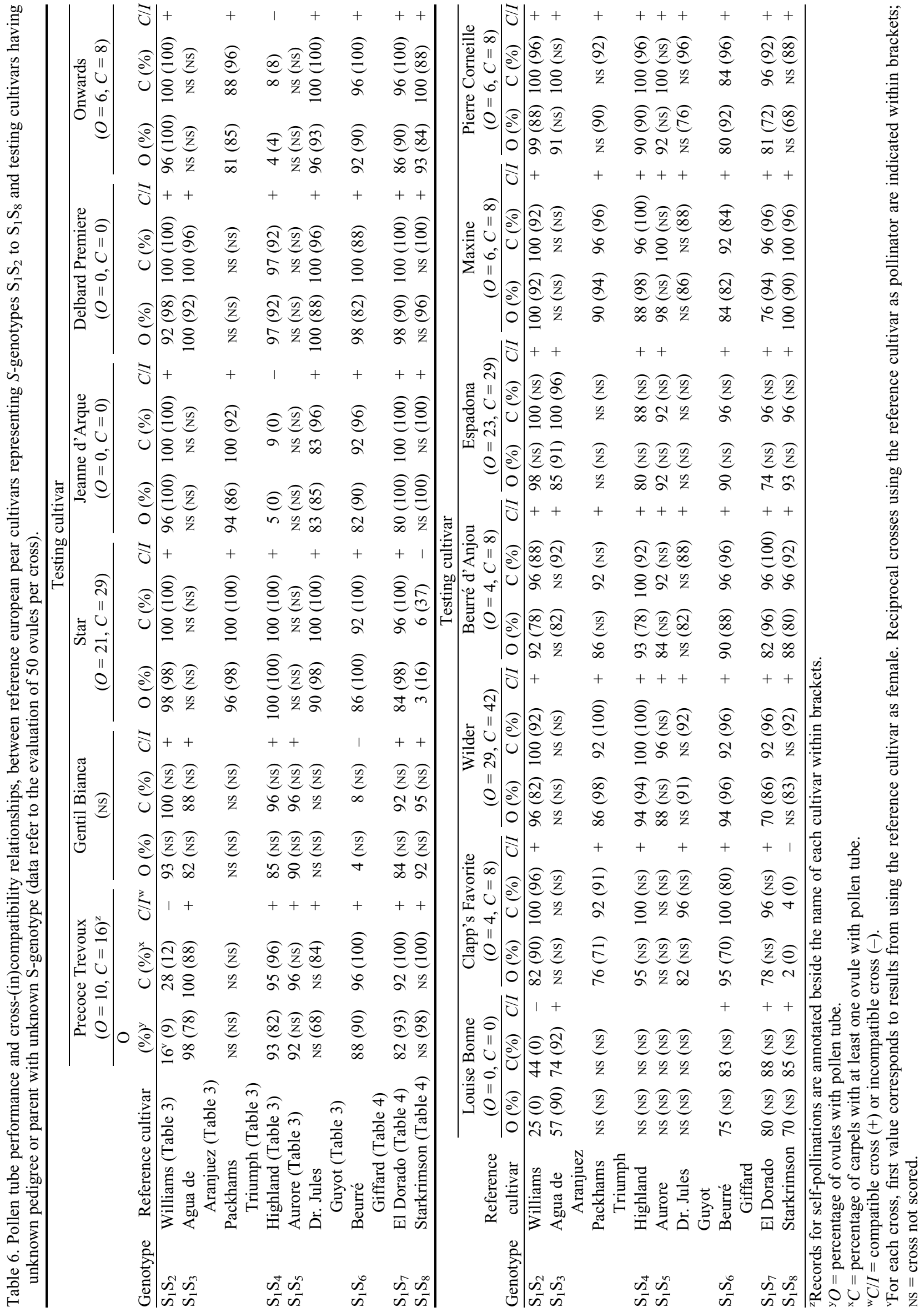

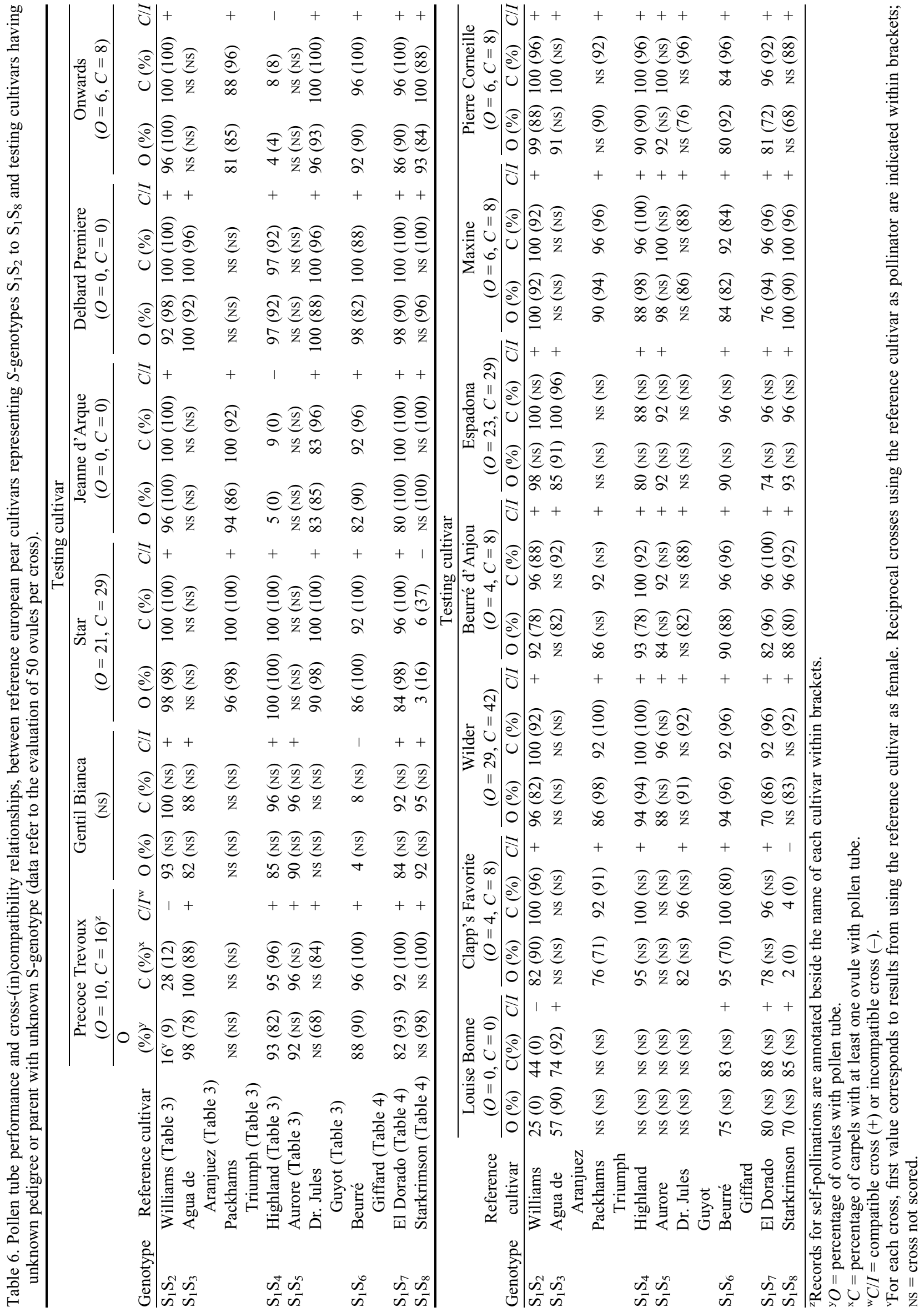

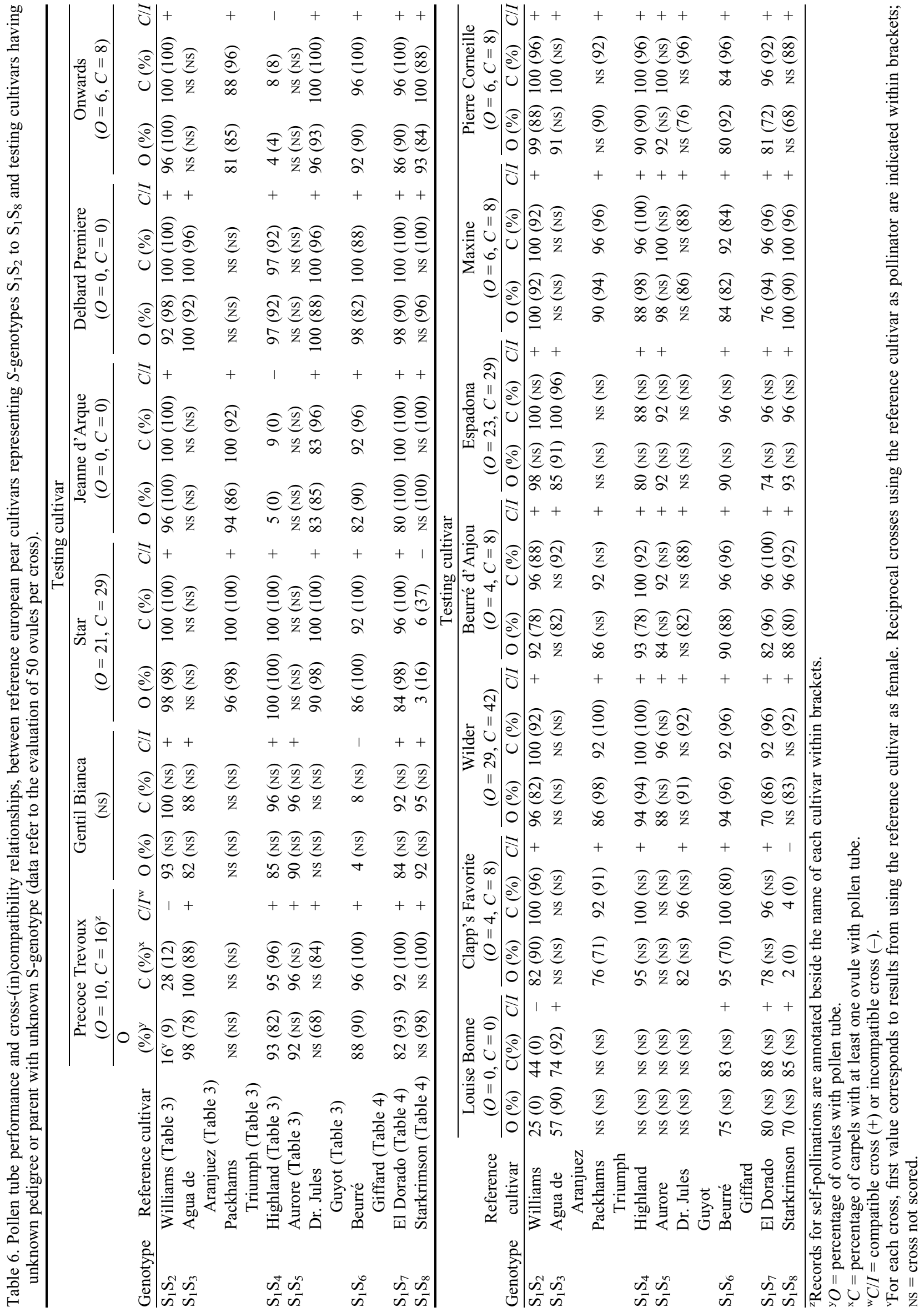

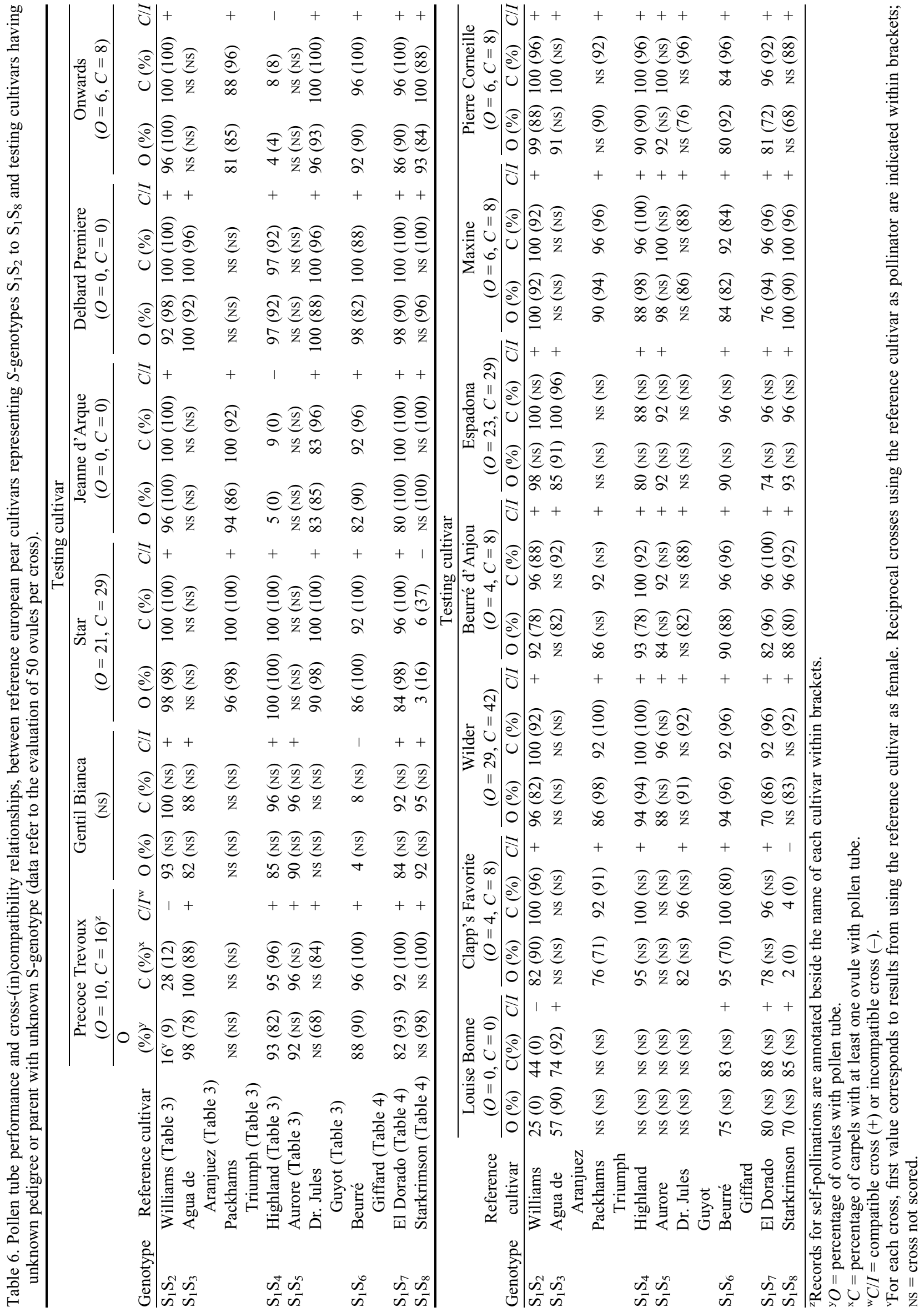

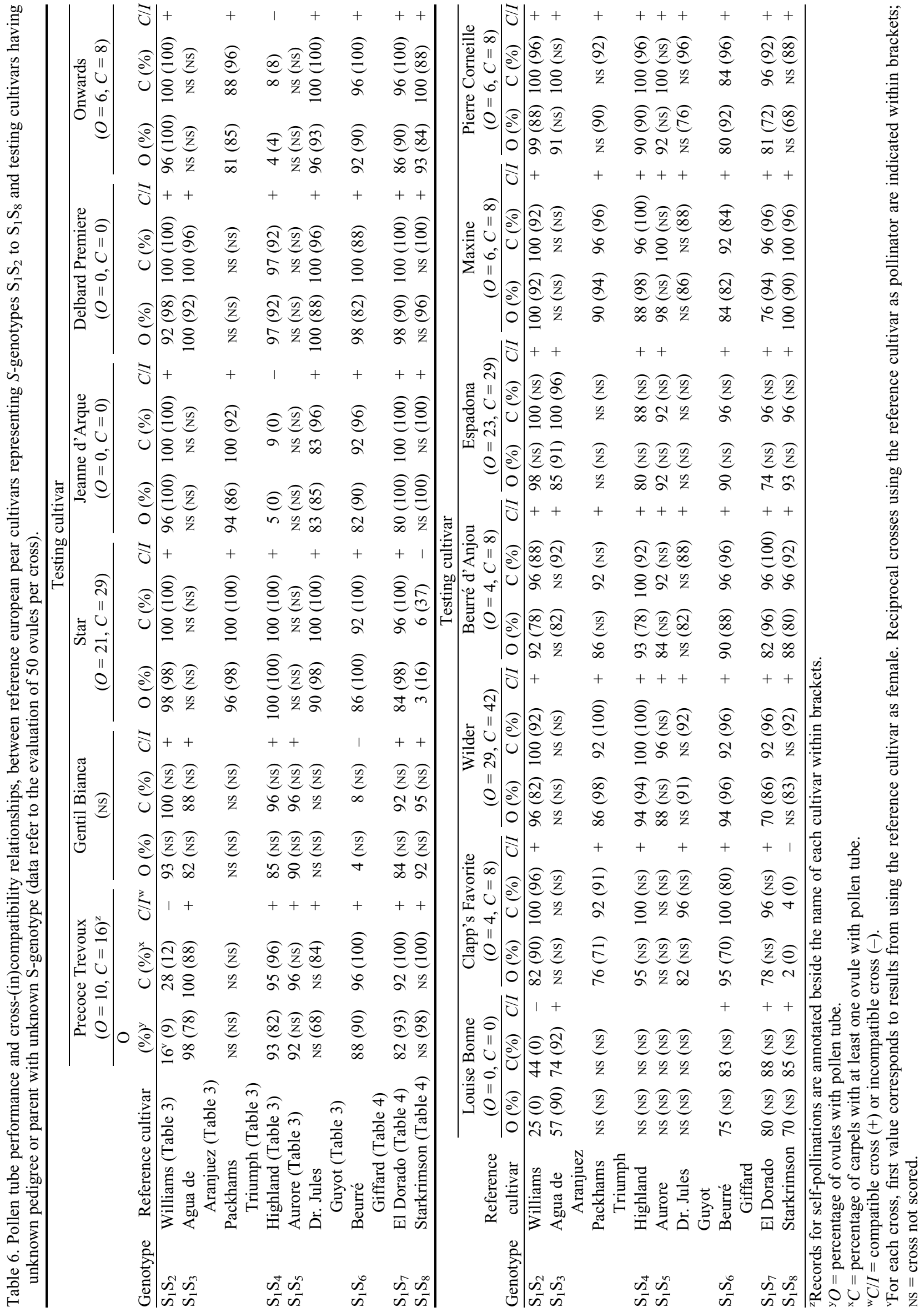


Table 7. Diallele cross involving the european pear cultivars that were shown to be cross-compatible with all the reference cultivars representing genotypes $\mathrm{S}_{1} \mathrm{~S}_{2}$ to $\mathrm{S}_{1} \mathrm{~S}_{8}$ (data refer to the evaluation of 50 ovules per cross).

\begin{tabular}{|c|c|c|c|c|c|c|c|c|c|c|c|c|c|c|c|c|c|c|}
\hline \multirow[b]{3}{*}{ Pollinated cultivar } & \multicolumn{18}{|c|}{ Pollinator cultivar } \\
\hline & \multicolumn{3}{|c|}{$\begin{array}{c}\text { Delbard } \\
\text { Premiere }\end{array}$} & \multicolumn{3}{|c|}{ Espadona } & \multicolumn{3}{|c|}{ Wilder } & \multicolumn{3}{|c|}{$\begin{array}{c}\text { Pierre } \\
\text { Corneille }\end{array}$} & \multicolumn{3}{|c|}{ Maxine } & \multicolumn{3}{|c|}{$\begin{array}{c}\text { Beurré d' } \\
\text { Anjou }\end{array}$} \\
\hline & $\begin{array}{c}O \\
(\%)^{\mathrm{z}}\end{array}$ & $\begin{array}{c}C \\
(\%)^{y}\end{array}$ & $C / I^{\mathrm{x}}$ & $\begin{array}{c}O \\
(\%)\end{array}$ & $\begin{array}{c}\mathrm{C} \\
(\%)\end{array}$ & $C / I$ & $\begin{array}{c}O \\
(\%)\end{array}$ & $\begin{array}{c}\mathrm{C} \\
(\%)\end{array}$ & $C / I$ & $\begin{array}{c}O \\
(\%)\end{array}$ & $\begin{array}{c}\mathrm{C} \\
(\%)\end{array}$ & $C / I$ & $\begin{array}{c}O \\
(\%)\end{array}$ & $\begin{array}{c}\mathrm{C} \\
(\%)\end{array}$ & $C / I$ & $\begin{array}{c}O \\
(\%)\end{array}$ & $\begin{array}{c}\mathrm{C} \\
(\%)\end{array}$ & $C / I$ \\
\hline Delbard Premiere & & Table 6 & & 90 & 96 & + & 88 & 96 & + & 74 & 92 & + & 76 & 88 & + & 92 & 96 & $\overline{+}$ \\
\hline Espadona & 81 & 92 & + & & able 6 & & & NS & & 72 & 84 & + & & NS & & & NS & \\
\hline Wilder & 94 & 96 & + & 90 & 100 & + & & Table 6 & & 86 & 92 & + & 90 & 100 & + & 88 & 92 & + \\
\hline Pierre Corneille & 84 & 84 & + & 100 & 100 & + & 96 & 100 & + & & Table 6 & & & NS & & 100 & 100 & + \\
\hline Maxine & 92 & 100 & + & 100 & 100 & + & 94 & 100 & + & 90 & 96 & + & & Table 6 & & 96 & 100 & + \\
\hline Beurré d'Anjou & 96 & 100 & + & 90 & 92 & + & 92 & 92 & + & 90 & 100 & + & 84 & 88 & + & & Table 6 & \\
\hline
\end{tabular}

${ }^{\mathrm{z}} \mathrm{O}=$ percentage of ovules with pollen tube.

${ }^{\mathrm{y}} \mathrm{C}=$ percentage of carpels with at least one ovule with pollen tube.

${ }^{\mathrm{x}} \mathrm{C} / \mathrm{I}=$ compatible cross $(+)$ or incompatible cross $(-)$.

${ }^{\mathrm{w}_{\mathrm{NS}}}=$ cross not scored.

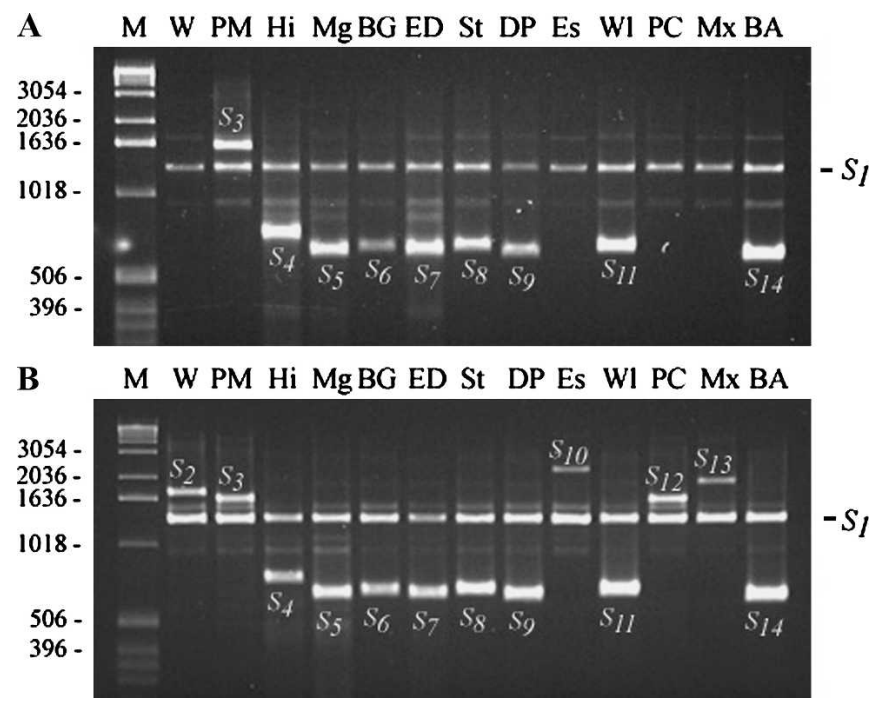

Fig. 2. PCR amplification of reference european pear cultivars representing the 13 S-genotypes discriminated in this study, using (A) degenerate primers $\mathrm{MPyC} 1 \mathrm{~F} / \mathrm{MPyC} 5 \mathrm{R}$ and $(\mathbf{B})$ consensus primers PycomC1F/PycomC5R. $\mathrm{M}=$ 1-kb molecular marker, $\mathrm{W}=$ 'Williams' $\left(\mathrm{S}_{1} \mathrm{~S}_{2}\right), \mathrm{PM}=$ 'Precoce Morettini' $\left(\mathrm{S}_{1} \mathrm{~S}_{3}\right), \mathrm{Hi}=$ 'Highland' $\left(\mathrm{S}_{1} \mathrm{~S}_{4}\right), \mathrm{Mg}=$ 'Magness' $\left(\mathrm{S}_{1} \mathrm{~S}_{5}\right), \mathrm{BG}=$ 'Beurré Giffard' $\left(\mathrm{S}_{1} \mathrm{~S}_{6}\right), \mathrm{ED}=$ 'El Dorado' $\left(\mathrm{S}_{1} \mathrm{~S}_{7}\right), \mathrm{St}=$ 'Starkrimson' $\left(\mathrm{S}_{1} \mathrm{~S}_{8}\right), \mathrm{DP}=$ 'Delbard Premiere' $\left(\mathrm{S}_{1} \mathrm{~S}_{9}\right)$, Es = 'Espadona' $\left(\mathrm{S}_{1} \mathrm{~S}_{10}\right), \mathrm{Wl}=$ 'Wilder' $\left(\mathrm{S}_{1} \mathrm{~S}_{11}\right)$, $\mathrm{PC}=$ 'Pierre Corneille' $\left(\mathrm{S}_{1} \mathrm{~S}_{12}\right), \mathrm{Mx}=$ 'Maxine' $\left(\mathrm{S}_{1} \mathrm{~S}_{13}\right), \mathrm{BA}=$ 'Beurré d'Anjou' $\left(\mathrm{S}_{1} \mathrm{~S}_{14}\right)$

primers, a product of 1600 bp was expected for both $S_{3}$ and $S_{12}$ (Fig. 2B). All the cultivars belonging to the incompatibility group $\mathrm{S}_{1} \mathrm{~S}_{3}$ amplified this product size, as did Pierre Corneille, the only cultivar assigned to the incompatibility group $\mathrm{S}_{1} \mathrm{~S}_{12}$. The S-genotypes from these cultivars were further explored with allele-specific PCR for $\mathrm{S}_{12}$. No amplification was obtained from 'Agua de Aranjuez', 'Precoce Morettini', 'Precoce di Fiorano', or 'Packhams Triumph', while the expected 1177-bp amplification (Table 2) was obtained for 'Pierre Corneille' (Table 9).

Cultivars amplifying the 675-bp product with consensus primers were scored with specific PCR for $\mathrm{S}_{6}, \mathrm{~S}_{8}$, and $\mathrm{S}_{11}$ (Table 2). The banding pattern (Fig. 3) was consistent with the S-phenotypes assigned to each cultivar (Table 9). 'Beurré Giffard' and 'Gentile Bianca', both assigned to $\mathrm{S}_{1} \mathrm{~S}_{6}$, amplified the 472-bp product corresponding to $S_{6}$. Similarly, 'Starkrimson',
'Sierra', 'Clapp's Favorite', and 'Star', all with S-phenotypes $\mathrm{S}_{1} \mathrm{~S}_{8}$, gave the $\mathrm{S}_{8}$-specific amplification. Wilder was the only cultivar assigned to $\mathrm{S}_{1} \mathrm{~S}_{11}$ and was the only cultivar amplifying the 560-bp product expected for $\mathrm{S}_{11}$. Finally, cultivars amplifying the 650 -bp product with consensus primers were tested with allele-specific PCR for $\mathrm{S}_{5}, \mathrm{~S}_{7}, \mathrm{~S}_{9}$, and $\mathrm{S}_{14}$ (Fig. 4). Results from this analysis were also consistent with the grouping of cultivars according to their S-phenotypes (Table 9).

Concluding Remarks. For 30 out of the 33 cultivars analyzed in this study, the $S$-phenotypes are assigned for the first time. The $S$-phenotype for 'Williams', 'Precoce Morrettini', and 'Agua de Aranjuez' had been previously reported (Sanzol and Herrero, 2002). From these 30 cultivars, the S-RNase genotypes of 14 have been published (Table 9). Following the correspondence reported between $S$-RNase alleles (Table 8), the S-phenotypes and S-genotypes assigned in this work are in accordance with the S-genotypes published by other groups, with the exception of 'Pierre Corneille'. The SRNase associated with the $S_{12}$ allele of this cultivar differs by six amino acids from the sequence reported for the $S_{q}$ RNase (Takasaki et al., 2006). The S-allele constitutions for the other 16 cultivars are described in this work for the first time.

During the last years the S-genotype for a substantial number of cultivars has been published (Moriya et al., 2007; Sanzol and Herrero, 2002; Sanzol et al., 2006; Takasaki et al., 2006; Zisovich et al., 2004; Zuccherelli et al., 2002). This information promises to assist nurseries, growers, and breeders in selecting compatible combinations of cultivars. Obviously, this work has been facilitated by the availability of molecular tools that exploit the sequence diversity present at the S-RNase gene. Here we have developed consensus and allele-specific PCR methods for the S-genotyping of $14 \mathrm{~S}$-alleles. Consensus and allele-specific PCR methods are being widely used for the discrimination of S-RNase alleles in the Rosaceae (Janssens et al., 1995; Sonneveld et al., 2003; Wu et al., 2007), including european pear (Sanzol et al., 2006; Zisovich et al., 2004). The main advantage of this methodology over restriction analysis is that it provides a simple plus/minus assay that is easily scored in a PCR reaction.

Molecular genotyping has several intrinsic limitations that should not be ignored. First, it may be insensitive toward unknown S-alleles; therefore, it is important to complement these methods with a reliable and efficient in vivo test to control 
Table 8. Correspondence between the $S$-RNases associated with alleles $\mathrm{S}_{1}$ to $\mathrm{S}_{14}$ and $\mathrm{S}$-RNases previously reported for european pear cultivars.

\begin{tabular}{|c|c|c|c|c|c|}
\hline \multicolumn{3}{|c|}{ Our work } & \multicolumn{3}{|c|}{ Letter-based labeling system } \\
\hline S-RNase & Reference cultivar & Sequence report & S-RNase & Reference cultivar & Sequence report \\
\hline$\overline{S_{1}}$ & Williams & Sanzol et al., 2006 & $\mathrm{~S}_{\mathrm{e}}, \mathrm{S}_{\mathrm{j}}$ & Spadona & Zisovich et al., 2004 \\
\hline $\mathrm{S}_{2}$ & Williams & Sanzol et al., 2006 & $\mathrm{~S}_{1}$ & Spadochina & Zisovich et al., 2004 \\
\hline $\mathrm{S}_{4}$ & Doyenne du Comice & Sanzol et al., 2006 & $\mathrm{~S}_{\mathrm{b}}$ & Doyenne du Comice & Zuccherelli et al., 2002 \\
\hline $\mathrm{S}_{5}$ & Doyenne du Comice & Sanzol et al., 2006 & $\mathrm{~S}_{\mathrm{a}}$ & Doyenne du Comice & Zuccherelli et al., 2002 \\
\hline $\mathrm{S}_{6}$ & Beurré Giffard & This work & $\mathrm{S}_{\mathrm{i}}$ & Gentile & Zisovich et al., 2004 \\
\hline $\mathrm{S}_{8}$ & Starkrimson & This work & $\mathrm{S}_{\mathrm{d}}$ & Beurré Hardy & Zuccherelli et al., 2002 \\
\hline $\mathrm{S}_{9}$ & Delbard Premiere & This work & $\mathrm{S}_{\mathrm{p}}$ & Delbard Premiere & Zisovich et al., 2004 \\
\hline $\mathrm{S}_{10}$ & Espadona & This work & $\mathrm{S}_{\mathrm{g}}$ & Passe Crassane & Morilla et al., 2007 \\
\hline $\mathrm{S}_{11}$ & Wilder & This work & $\mathrm{S}_{\mathrm{s}}$ & Dona's Hovay & Morilla et al., 2007 \\
\hline $\mathrm{S}_{12}$ & Pierre Corneille & This work & & & \\
\hline $\mathrm{S}_{13}$ & Maxine & This work & $\mathrm{S}_{\mathrm{t}}$ & Maxine & Morilla et al., 2007 \\
\hline
\end{tabular}

Table 9. S-genotype analysis of the 33 european pear cultivars assigned to 13 incompatibility groups.

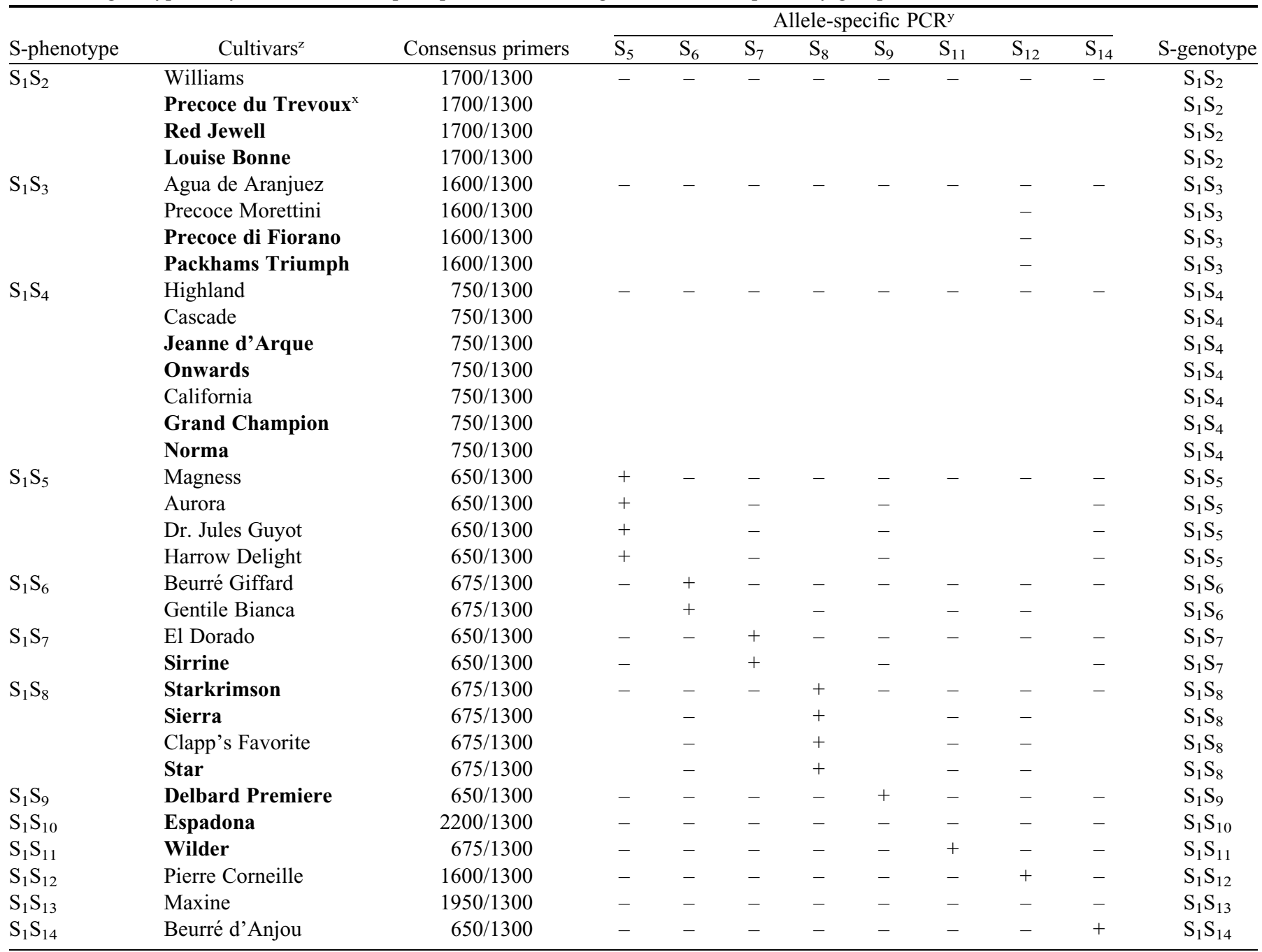

zThe S-RNase genotype of 14 cultivars has been previously reported: 'Williams' and 'Cascade' (Zuccherelli et al., 2002); 'Dr. Jules Guyot' and 'Gentile' (Zisovich et al., 2004); 'Agua de Aranjuez' and 'Precoce Morettini' (Sanzol et al., 2006); 'Aurora', 'Magness', 'Harrow Delight', 'Highland', 'California', 'Clapp‘s Favorite', 'El Dorado', and 'Pierre Cornelle' (Takasaki et al., 2006); 'Beurré Giffard', 'Maxine', and 'Beurré d'Anjou' (Moriya et al., 2007).

yPresence $(+)$ or absence $(-)$ of specific amplification after allele-specific PCR.

${ }^{x}$ Cultivars with S-RNase genotype described in this work for the first time are indicated in bold. 


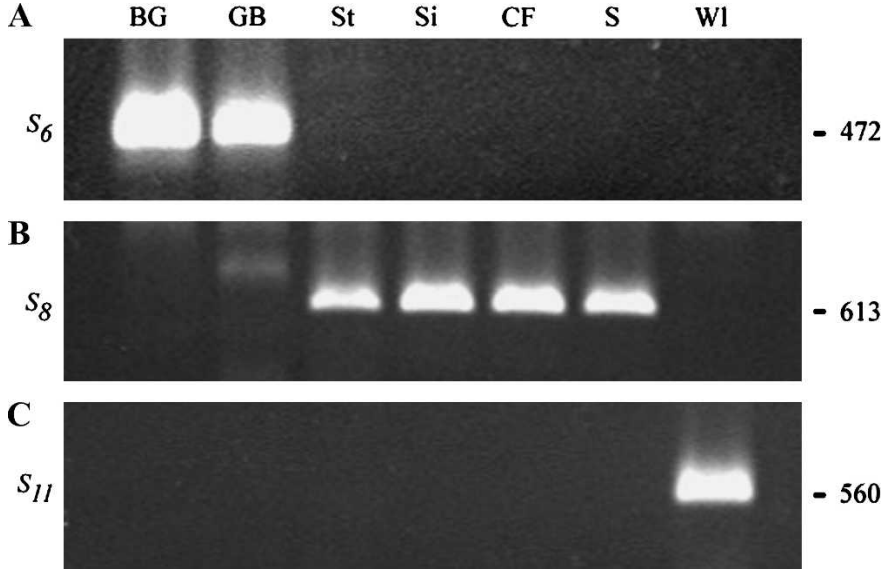

Fig. 3. Allele-specific PCR for european pear cultivars amplifying an S-RNase product of $\approx 675$ bp with consensus primers $(A)$ allele-specific for $\mathrm{S}_{6}$, (B) allele-specific PCR for $\mathrm{S}_{8}$, and $(C)$ allele-specific for $\mathrm{S}_{11}$. Lanes from the left are $\mathrm{BG}=$ 'Beurré Giffard' $\left(\mathrm{S}_{1} \mathrm{~S}_{6}\right)$, $\mathrm{GB}=$ 'Gentile Bianca' $\left(\mathrm{S}_{1} \mathrm{~S}_{6}\right)$, St = 'Starkrimson' $\left(\mathrm{S}_{1} \mathrm{~S}_{8}\right), \mathrm{Si}=$ 'Sierra' $\left(\mathrm{S}_{1} \mathrm{~S}_{8}\right), \mathrm{CF}=$ 'Clapp's Favorite' $\left(\mathrm{S}_{1} \mathrm{~S}_{8}\right), \mathrm{S}=$ 'Star' $\left(\mathrm{S}_{1} \mathrm{~S}_{8}\right)$, and $\mathrm{Wl}=$ 'Wilder' $\left(\mathrm{S}_{1} \mathrm{~S}_{11}\right)$.

putative new specificities. In this study we have reported on the use of semicompatible reference S-genotypes allowing a putative new S-allele to be scored whenever it is found in combination with the $S_{1}$ allele. Second, recent findings in other species of the Rosaceae suggest that sharing the same S-RNase protein does not guarantee the identity between two S-alleles (Šurbanovski et al., 2007). Finally, the S-genotype of a european pear cultivar does not strictly predict its performance in terms of self-fertility or cross-fertility with other cultivars sharing the same S-genotype. Results in this study present a wide analysis of the fertility of european pear cultivars under self- and cross-incompatible pollinations. The data obtained confirm previous observations from fruit and seed set data
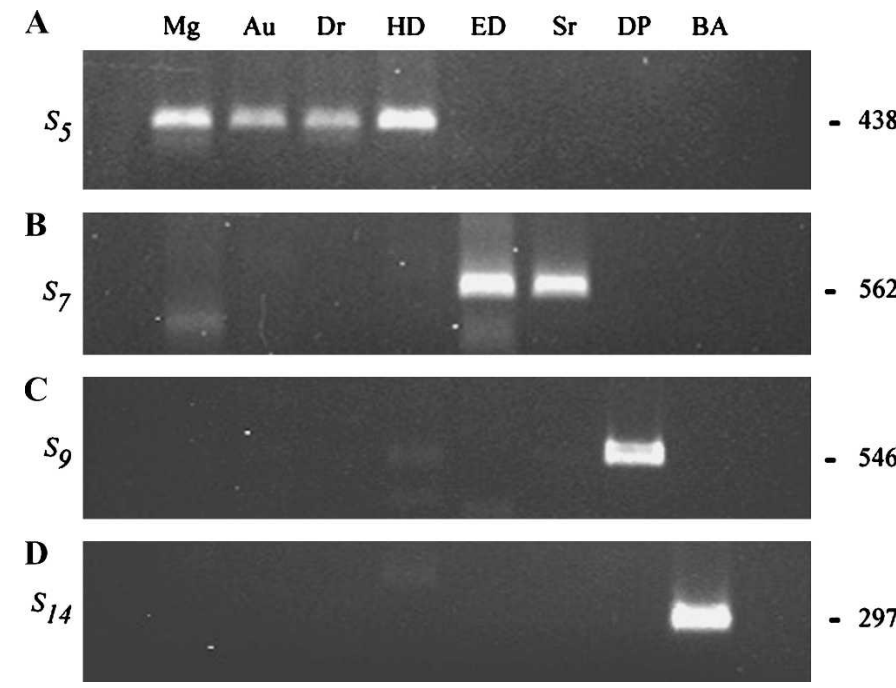

Fig. 4. Allele-specific PCR for european pear cultivars amplifying an S-RNase product of $\approx 650 \mathrm{bp}$ with consensus primers (A) allele-specific PCR for $\mathrm{S}_{5}$, (B) allele-specific PCR for $\mathrm{S}_{7},(\mathrm{C})$ allele-specific PCR for $\mathrm{S}_{9}$, and (D) allelespecific PCR for $\mathrm{S}_{14}$. Lanes from the left are $\mathrm{Mg}=$ 'Magness' $\left(\mathrm{S}_{1} \mathrm{~S}_{5}\right), \mathrm{Au}=$ 'Aurora' $\left(\mathrm{S}_{1} \mathrm{~S}_{5}\right), \mathrm{Dr}=$ 'Dr. Jules Gujot' $\left(\mathrm{S}_{1} \mathrm{~S}_{5}\right), \mathrm{HD}=$ 'Harrow Delight' $\left(\mathrm{S}_{1} \mathrm{~S}_{5}\right)$, $\mathrm{ED}=$ 'El Dorado' $\left(\mathrm{S}_{1} \mathrm{~S}_{7}\right), \mathrm{Sr}=$ 'Sirrine' $\left(\mathrm{S}_{1} \mathrm{~S}_{7}\right), \mathrm{DP}=$ 'Delbard Premiere' $\left(\mathrm{S}_{1} \mathrm{~S}_{9}\right)$, and $\mathrm{BA}=$ 'Beurré d'Anjou' $\left(\mathrm{S}_{1} \mathrm{~S}_{14}\right)$.
(Crane and Lewis, 1942) and pollen tube performance (Lewis and Modlibowska, 1942; Sanzol and Herrero, 2002) showing that the intensity of the incompatibility reaction in european pear varies strongly among cultivars, probably due to the action of one or several modifier genes (Zuccherelli et al., 2002). Recently, we have shown how slight differences in the level of selfing can have a great impact on the variation of cropping for the cultivar Agua de Aranjuez (Sanzol and Herrero, 2007). Therefore two self-incompatible cultivars can behave differently regarding their cropping ability under self-pollination. Similarly, two cultivars sharing the same S-alleles may substantially differ regarding their ability to be crossed.

\section{Literature Cited}

Bernacchi, D. and S.D. Tanksley. 1997. An interspecific backcross of Lycopersicon esculentum $\times$ L. hirsutum: Linkage analysis and a QTL study of sexual compatibility factors and floral traits. Genetics 147:861-877.

Bošković, R. and K.R. Tobutt. 1996. Correlation of stylar ribonuclease zymograms with incompatibility alleles in sweet cherry. Euphytica 90:245-250.

Broothaerts, W., G.A. Janssens, P. Proost, and W.F. Broekaert. 1995. cDNA cloning and molecular analysis of two self-incompatibility alleles from apple. Plant Mol. Biol. 27:499-511.

Burke, J.M., S. Tang, S.J. Knapp, and L.H. Rieseberg. 2002. Genetic analysis of sunflower domestication. Genetics 161:12571267.

Crane, M.B. and A.G. Brown. 1937. Incompatibility and sterility in sweet cherry, Prunus avium L. J. Pomol. Hort. Sci. 15:86-116.

Crane, M.B. and D. Lewis. 1942. Genetical studies in pears. III. Incompatibility and sterility. J. Genet. 43:31-44.

de Nettancourt, D. 2001. Incompatibility and incongruity in wild and cultivated plants. Springer, Berlin.

Gandhi, S.D., A.F. Heesacker, C.A. Freeman, J. Argyris, K. Bradford, and S.J. Knapp. 2005. The self-incompatibility locus $(S)$ and quantitative trait loci for self-pollination and seed dormancy in sunflower. Theor. Appl. Genet. 111:619-629.

Griggs, W.H. and B.T. Iwakiri. 1954. Pollination and parthenocarpy in the production of 'Bartlett' pears in California. Hilgardia 22: 643-678.

Ishimizu, T., K. Inoue, M. Shimonaka, T. Saito, O. Terai, and S. Norioka. 1999. PCR-based method for identifying the S-genotypes of japanese pear cultivars. Theor. Appl. Genet. 98:961-967.

Janssens, G.A., I.J. Goderis, W.F. Broekaert, and W. Broothaerts. 1995. A molecular method for S-allele identification in apple based on allele-specific PCR. Theor. Appl. Genet. 91:691-698.

Kester, D.E., T.M. Gradziel, and W.C. Micke. 1994. Identifying pollen incompatibility groups in California almond cultivars. J. Amer. Soc. Hort. Sci. 119:106-109.

Kobel, F., P. Steinegger, and J. Anliker. 1939. Weitere Untersuchungen über die Befruchtungsverhältnisse der Apfel- und Birnsorten. Landw. Jahrb. Schweiz. 53:160-191.

Le Lézec, M. 1998. Pollinisation du poirier. Arboricult. Fruit. 520: $37-40$.

Lewis, D. and I. Modlibowska. 1942. Genetical studies in pears. IV. Pollen-tube growth and incompatibility. J. Genet. 43:211-222.

Modlibowska, I. 1945. Pollen tube growth and embryo-sac development in apples and pears. J. Pomol. 21:57-89.

Moriya, Y., K. Yamamoto, K. Okada, H. Iwanami, H. Bessho, T. Nakanishi, and T. Takasaki. 2007. Development of a CAPS marker system for genotyping european pear cultivars harboring $17 \mathrm{~S}$ alleles. Plant Cell Rpt. 26:345-354.

Osterwalder, A. 1910. Blütenbiologie, Embriologie und Entwicklung der Frucht unserer Kernobstbäume. Landw. Jahrb. 39:917-998. 
Sanzol, J. and M. Herrero. 2002. Identification of self-incompatibility alleles in pear cultivars (Pyrus communis L.). Euphytica 128:325-331. Sanzol, J. and M. Herrero. 2007. Self-incompatibility and selffruitfulness in pear cv. Agua de Aranjuez. J. Amer. Soc. Hort. Sci. 132:166-171.

Sanzol, J., B.G. Sutherland, and T.P. Robbins. 2006. Identification and characterization of genomic DNA sequences of the S-ribonuclease gene associated with self-incompatibility alleles $S_{1}$ to $S_{5}$ in european pear. Plant Breed. 125:513-518.

Sonneveld, T., K.R. Tobutt, and T.P. Robbins. 2003. Allele-specific PCR detection of sweet cherry self-incompatibility alleles using consensus and allele-specific primers. Theor. Appl. Genet. 107: 1059-1070.

Šurbanovski, N., K.R. Tobutt, M. Konstantinovic, V. Maksimovic, D.J. Sargent, V. Stevanovic, E. Ortega, and R.I. Bošković. 2007. Self-incompatibility of Prunus tenella and evidence that reproductively isolated species of Prunus have different SFB alleles coupled with an identical S-RNase allele. Plant J. 50:723-734.

Takasaki, T., Y. Moriya, K. Okada, K. Yamamoto, H. Iwanami, H. Bessho, and T. Nakanishi. 2006. cDNA cloning of nine S alleles and establishment of a PCR-RFLP system for genotyping european pear cultivars. Theor. Appl. Genet. 112:1543-1552.

Tehrani, G. and J.W. Lay. 1991. Verification through pollen incompatibility studies of pedigrees of sweet cherry cultivars from Vineland. HortScience 26:190-191.
Thompson, J.D., T.J. Gibson, F. Plewniak, F. Jeanmougin, and D.G. Higgins. 1997. The ClustalX windows interface: Flexible strategies for multiple sequence alignment aided by quality analysis tools. Nucleic Acids Res. 25:4876-4882.

Thompson, J.M., T. van der Zwet, A.D. Draper, and R.L. Blake. 1976. Evidence of cytoplasmic and genetic male sterility in pears. J. Hered. 67:339-346.

Williams, W. and A.G. Brown. 1956. Genetic response to selection in cultivated plants; Gene frequencies in Prunus avium. Heredity 10:237-245.

Wu, H.Q., S.L. Zhang, and H.Q. Qu. 2007. Molecular and genetic analyses of $\mathrm{S}_{4}{ }^{\mathrm{SM}}$ RNase allele in japanese pear 'Osa-Nijisseiki' (Pyrus pyrifolia Nakai). Plant Breed. 126:77-82.

Yamamoto, T., T. Kimura, M. Shoda, T. Imai, T. Saito, Y. Sawamura, K. Kotobuki, T. Hayashi, and N. Matsuta. 2002. Genetic linkage maps constructed by using an interspecific cross between japanese and european pears. Theor. Appl. Genet. 106:9-18.

Zisovich, A.H., R.A. Stern, S. Shafir, and M. Goldway. 2004. Identification of S-alleles from the european pear (Pyrus communis L.) and the determination of compatibility among cultivars. J. Hort. Sci. Biotechnol. 79:101-106.

Zuccherelli, S., P. Tassinari, W. Broothaerts, S. Tartarini, L. Dondini, and S. Sansavini. 2002. S-allele characterization in self-incompatible pear (Pyrus communis L.). Sex. Plant Reprod. 15:153-158 